\title{
The Theoretically Studies and Field Testing of Self-Insulation Exterior Wall in the Hot Summer and Cold Winter Zone
}

\author{
Huifang Yu1,2, Quanbiao $\mathrm{Xu}^{2}$, Sanming Zhang ${ }^{3}$, Weijun Gao', Jianfeng $\mathrm{Xu}^{4^{*}}$ \\ ${ }^{1}$ Environmental Engineering, University of Kitakyushu, Kitakyushu, Japan \\ ${ }^{2}$ The Architectural Design \& Research Institute, Zhejiang University, Hangzhou, China \\ ${ }^{3}$ Department of architecture, Zhejiang University, Hangzhou, China \\ ${ }^{4}$ Shanghai Tunnel Engineering \& Rail Transit Design and Research Institute, Shanghai, China \\ Email: *987127368@qq.com
}

How to cite this paper: $\mathrm{Yu}, \mathrm{H} . \mathrm{F} ., \mathrm{Xu}, \mathrm{Q} . \mathrm{B}$., Zhang, S.M., Gao, W.J. and Xu, J.F. (2017) The Theoretically Studies and Field Testing of Self-Insulation Exterior Wall in the Hot Summer and Cold Winter Zone. Energy and Power Engineering, 9, 654-686. https://doi.org/10.4236/epe.2017.910043

Received: August 10, 2017

Accepted: September 19, 2017

Published: September 22, 2017

Copyright (c) 2017 by authors and Scientific Research Publishing Inc. This work is licensed under the Creative Commons Attribution International License (CC BY 4.0).

http://creativecommons.org/licenses/by/4.0/

\begin{abstract}
The energy efficiency design of the exterior wall in the buildings of the hot summer and cold winter zone of China should consider the heat prevention in summer and the heat insulation in winter. The self-insulation of the exterior wall is a more feasible design to satisfy the energy efficiency of buildings in the zone. However, the systematic research is urgently needed for the self-insulation of the exterior wall in the hot summer and cold winter zone of China. The paper tested the thermal performance of the common non-clay materials such as shale sintered hollow brick, sand autoclaved aerated concrete block, etc. by means of indoor experiments. The energy efficiency effect of the common materials was verified using dynamic calculation soft PKPM and several constitutions of exterior wall with different main bricks and insulation materials on the heat bridge were simulated, too. Besides, the tests of the thermal performance of exterior wall in real constructions were carried out to testify the practical effect of the recommended constitutions of exterior wall with different main bricks and insulation materials on the heat bridge. The conclusions are: the physical and thermal properties of the six non-clay wall material are better than the clay porous brick; the thermal performance of the non-clay brick can be improved obviously through the rational arrangement of the holes; shale sintered hollow brick after increasing the holes and rationalizing the hole arrangement and sand autoclaved aerated concrete block are recommended for buildings in the hot summer and cold winter area of China. The dynamic calculation results show that the thermal performances of the non-clay materials are all satisfied with the energy efficiency; The heat transfer coefficient of the exterior wall with composition (3), in
\end{abstract}


which the main wall was sand autoclaved aerated concrete block and the material on the heat bridge was sand autoclaved aerated concrete plate, is the smallest among the three recommended compositions.

\section{Keywords}

Self-Insulation Exterior Wall, Indoor Experiments, Dynamic Simulation, Field Testing, Hot Summer and Cold Winter Zone

\section{Introduction}

Building envelops can protect people from wicked natural environment. Appropriate building walls configurations not only provide comfortable indoor environment, but also decrease building operation energy consumption. Commonly, the thermal performance of the exterior wall can be improved by adding insulation materials on the inside or outside of the wall, which is interior insulation or exterior insulation. However, many problems are found in the practice of the interior insulation or exterior insulation.

The problems of the interior insulation are: the wall always go mouldy or craze because of exterior zone of the wall cannot be protect by the insulation materials; the insulation system craze easily, too; the effective use space of the building is smaller after the insulation materials adding on the interior face of the wall; the insulation system could be destroyed when building are decorated secondly; the transformation of the interior insulation disturb the people living in the building.

The problems of the exterior insulation are: the cost is high and the construction process is difficult; the quality control and monitor is difficult; the insulation system craze easily because of exposed to the meteorological changes; the fire resistance performance is worse.

The exterior wall with self-insulation can avoid the problems of the interior and exterior insulation. Therefore, more and more practices are adopted the self-insulation wall in the buildings.

There are extensive researches on insulation location of building wall. Sonderegger [1] used Fourier one-dimensional heat conduction equation and the matrix method to discuss of the thermal characteristics of buildings with different wall layer compositions. The conclusion is: For continuously operated buildings in climates with large daily temperature variations, high solar flux and large fluctuations in internal heat source profiles, the inside placement of the wall mass, preferably masonry, appears advantageous; Buildings situated in extreme climates with small daily temperature variations, where intermittent occupancy schedules allow for frequent temperature setbacks of large magnitude, should have the insulation placed on the inside surface of the walls.

Bojic et al. [2] employed the detailed building heat transfer simulation program HTB2 to calculate the yearly cooling loads of two typical flats in a residential 
+building in Hong Kong in order to investigate the optimum position of thermal insulation in building envelope. They used $15 \mathrm{~cm}$ thick concrete and $5 \mathrm{~cm}$ of insulation layer. The location of insulation is being varied from the outer wall surface to the inner wall surface. They showed that for intermittently operated buildings, $11 \%$ energy savings are obtained when the insulation is placed at the inner surface of walls compared to placing it at the outer surface.

Kossecka and Kosny [3] used DOE-2.1E to investigate the influence of insulation position within exterior walls on heating and cooling loads in a continuously used building. The walls are composed of heavyweight concrete layer of constant thickness of $0.152 \mathrm{~m}$ and insulation layers of constant thickness of $0.102 \mathrm{~m}$. The insulation position is varied within the wall. The study is done for six different US climates. They reported that locating the insulation layer at the outer surface of the walls provides the best thermal performance. Differences in total energy demand between the configuration "all insulation inside" and the most effective configuration (from the point of view of energy savings) "all insulation outside" may exceed $11 \%$ for a continuously used building for all the different climate zones.

Zhu and Zhang [4] investigated the air condition energy of the same residential building in three different climate regions of China by using the building thermal environment simulation Toolkit DeST. They analyzed the effects of outside wall heat preservation form and layer thicknesses on air conditioning. The effect of moving mode of air conditioning and natural ventilation mode has been discussed in this paper. They reported that exterior insulation is more favorable in reducing air conditioning load than interior insulation for all the three climate regions, the advantage of exterior insulation is more obvious when the natural ventilation rate increases and the mode of air conditioning is intermittent.

Ning et al. [5] analyzed the year-round energy consumption of different exterior wall heat insulation of a residential building without interior heat source in hot summer and cold winter zone of China by the building thermal environment simulation Toolkit DeST. They concluded that exterior insulation is a little bit better than interior insulation in the view of annual energy consumption.

Tsilingiris [6] investigated the best location of insulation layer in walls without presence of windows under the effect of intermittent heating for a typical winter weather conditions representative of a mild Mediterranean climate. He reported that locating the insulation at the inner wall surface saves $30 \%-40 \%$ energy compared to locating the insulation at the outer face of the walls during intermittent operation of the building heating ventilation and air-conditioning (HVAC) system.

Ozel and Pihtili [7] studied performance of 12 wall configurations for multilayer walls of air-conditioned space in Elazig, Turkey during typical summer and winter days by the means of a numerical model based on implicit finite difference scheme. They concluded that locating the insulation at the inside surface of walls is the most energy efficient for an intermittently conditioned space for 
both heating and cooling. Conversely, for continuous conditioned buildings, locating the insulation outside has the best performance.

Yu et al. [8] used eQUEST software to analyze envelope design on energy saving of air conditioner (AC) and the effects of energy saving strategies on AC electric consumption of different orientation rooms of a residential building in hot summer and cold winter zone in China. The results indicate that the effect of thermal insulation on AC system cooling electric consumption is not obvious, interior insulation is lowest and middle insulation is highest.

Ibrahim et al. [9] employed the transient one-dimensional heat conduction equation and space heat balance equations to optimize the position and thickness of insulation layers in building external wall for the coastal Mediterranean zone and the inland plateau of Lebanon. The conclusion is that locating the insulation at the inner surface reduces the wall load by about $15 \%$ compared to locating it at the middle of the wall for intermittent air-conditioning.

Kolaitis et al. [10] performed a comparative assessment of internal versus external thermal insulation systems for energy efficient retrofitting of residential buildings by means of detailed numerical simulations. They concluded that both external and internal thermal insulation configurations are found to significantly reduce the total energy requirements; on average, external insulation outperforms the internal insulation configuration by $8 \%$.

What can be seen from the above literatures is that the most researches are focus on the thermal performance of the wall with added insulation such as interior or exterior insulation. The self-insulation of the exterior wall is rarely studied in the hot summer and cold winter zone of China.

The hot summer and cold winter zone of China is a main climate zone of China. It is consisted of 16 provinces, cities and municipalities. The area of the zone is about $1,800,000$ square kilometers and the population is about 55 millions. The energy efficiency design of the exterior wall in the buildings of the zone should consider the heat prevention in summer and the heat insulation in winter. Because of the serial problems found in the practical application of common insulation forms such as interior insulation and exterior insulation, another applicative insulation form of exterior wall should be put forward. The self-insulation of the exterior wall is a feasible design to satisfy the energy efficiency of buildings in the zone.

The self-insulation of the exterior wall is that the exterior wall is manufactured by insulation material, whose thermal conductivity is small. The thermal performance can satisfy the needs of the energy efficiency without added insulation on the exterior. However, the systematic research is urgently needed for the self-insulation of the exterior wall in the hot summer and cold winter zone of China.

The paper was aimed to test the thermal performance of the common materials using in the self-insulation of the exterior wall by means of indoor experiments. Besides, the energy efficiency effect of the common materials was verified using dynamic calculation soft PKPM and several constitutions of exterior wall 
with different main bricks and insulation materials on the heat bridge were simulated, too. Finally, the tests of the thermal performance of the exterior wall based on the real constructions were carried out to testify the practical effect of the recommended constitutions of exterior wall with different main bricks and insulation materials on the heat bridge.

\section{Indoor Experiment Researches of Thermal Physical}

According to the needs of building energy efficiency and wall materials innovation in the area of hot summer and cold winter of China, the main development direction of new wall, that is non-clay energy-saving wall basing on the local resources including industrial waste residues, urban river sludge, enterprise papermaking sludge recycling etc., is determined. The common non-clay wall materials are shale sintered hollow brick, sand autoclaved aerated concrete block, shale sintered porous brick, sintering gangue porous brick, sintering heat preservation brick, composite concrete porous brick, etc.

A series of experiment researches were conduct to test the thermal physical properties of the common non-clay wall materials and determine whether conform to the requirements of the heat preservation of wall materials in the codes. By comprehensive comparison, one or two kinds of insulation wall materials most suitable for the hot summer and cold winter area of China was selected.

The main test instruments were JW-I type (Figure 1) test instrument for building wall and glass products, JW-II type (Figure 2) temperature and heat flux auto detector, voltage regulator and computer for recording data.

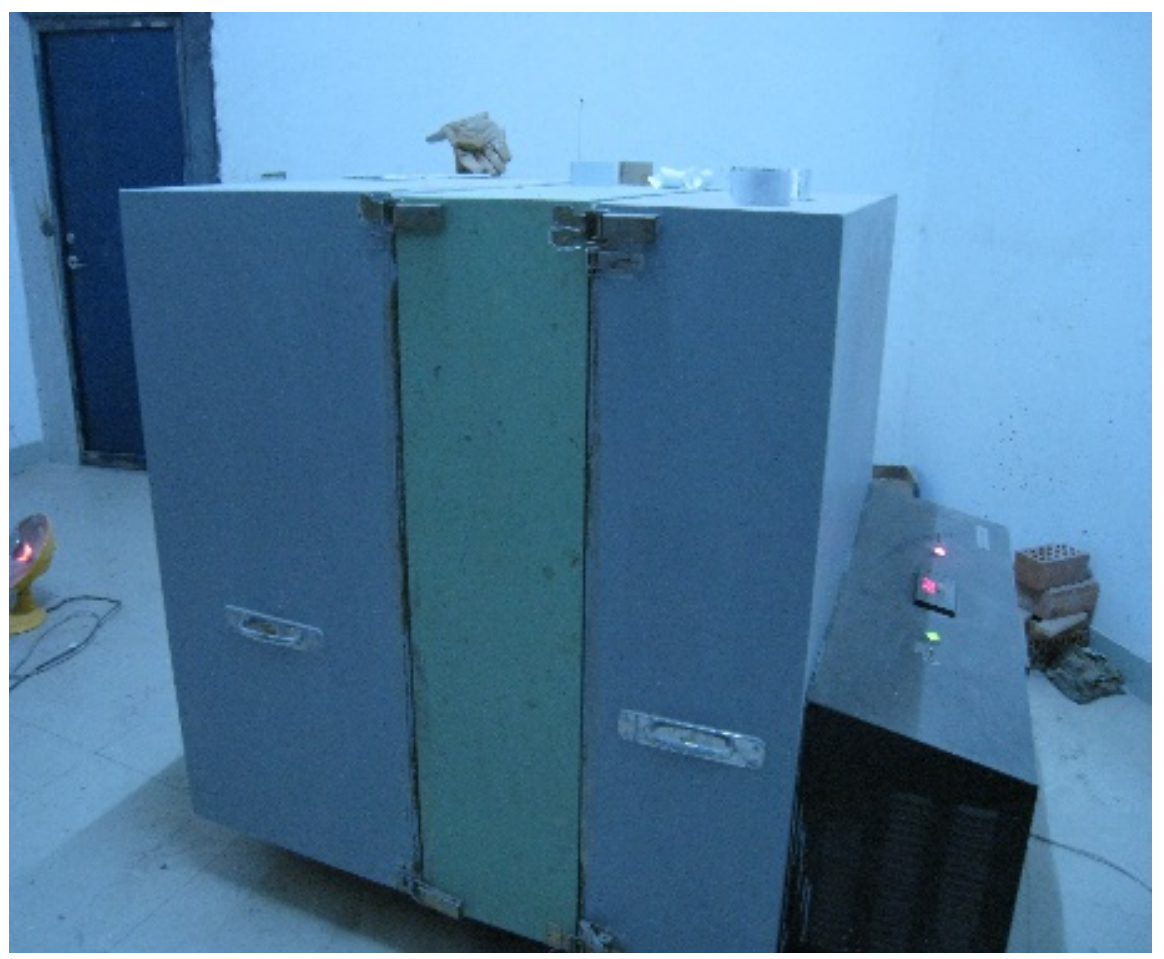

Figure 1. JW-I type test instrument. 


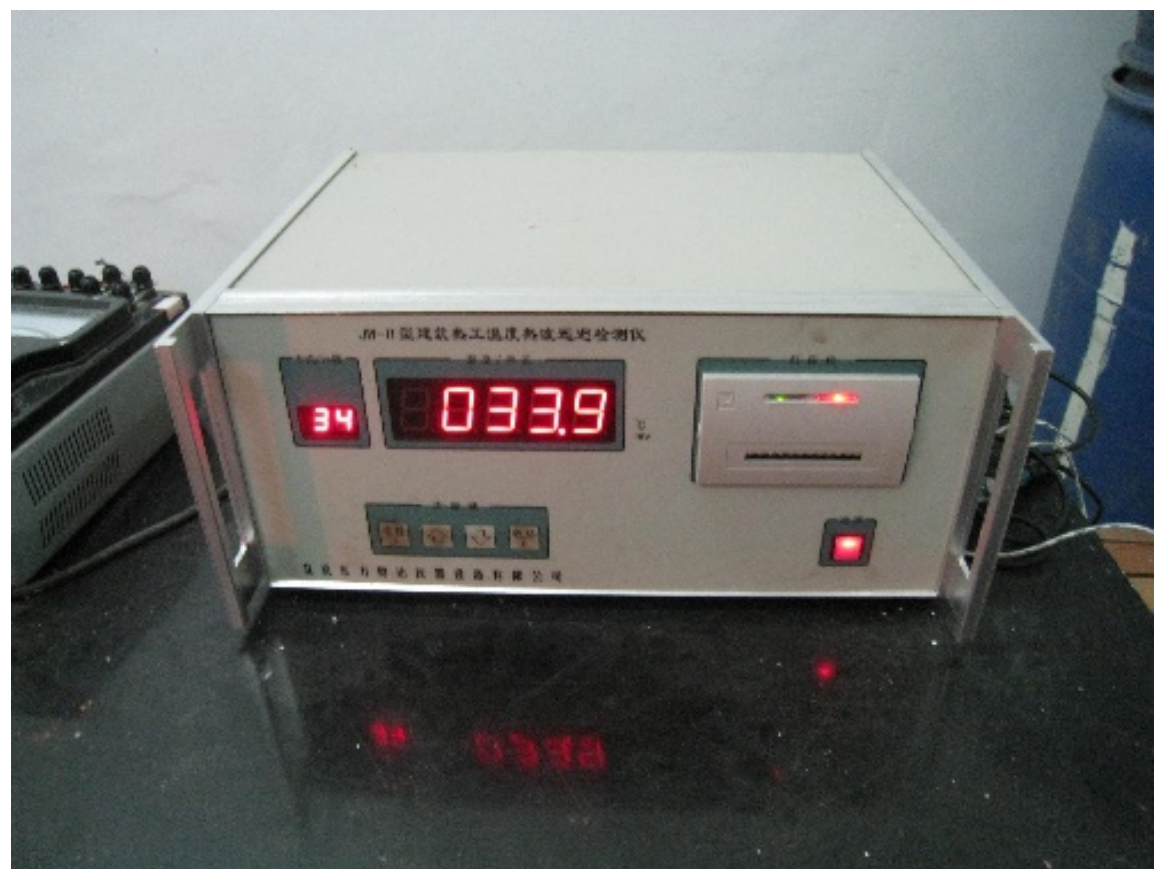

Figure 2. JW-II type test instrument.

The JW-II type temperature and heat flux auto detector is an intelligent data recording and analysis instrument, including 55 temperature detecting routes and 20 heat flux detecting routes. Besides, it can upload the data to the computer for analyzing. The dimension of WYP heat flux meter is $110 \mathrm{~mm} \times 110 \mathrm{~mm} \times$ $2.5 \mathrm{~mm}$, the measuring probe coefficient is $11.6 \mathrm{w} /\left(\mathrm{m}^{2} \cdot \mathrm{mv}\right)\left(10 \mathrm{kcal} / / \mathrm{m}^{2} \cdot \mathrm{h} \cdot \mathrm{mv}\right)$, the measuring temperature range is below $100^{\circ} \mathrm{C}$ and the measuring error is $\leq 5 \%$. The temperature sensors for the experiments are Copper-Constantan thermocouples, whose temperature measuring range is $-50^{\circ} \mathrm{C}$ to $100^{\circ} \mathrm{C}$, resolution ratio is $0.1^{\circ} \mathrm{C}$ and uncertainty is $\leq+0.5^{\circ} \mathrm{C}$. Besides, the digital thermometer, whose resolution ratio is $0.1^{\circ} \mathrm{C}$, temperature measuring range is $-50^{\circ} \mathrm{C}$ to $199.9^{\circ} \mathrm{C}$ and accuracy ratio is $\leq+\left(0.3 \%+1^{\circ} \mathrm{C}\right)$, is also used in the experiments.

A testing wall, whose dimension is $1000 \mathrm{~mm} \times 1000 \mathrm{~mm}$ and the thickness depending on the thickness of the test wall, was built in the test-specimen shelf of JW-I type test instrument. The thermal resistance and heat transfer coefficient of the test wall can be computed after the heat flux and the temperature of the wall were measured. Before experiment, every wall test-specimen was dried by warmer (Figure 3) to avoid the influence of water in the material. The heat flux meter and the temperature sensors were pasted on the both sides of the test wall (Figure 4). The both sides of the test wall were all against to a thermostat room, which was controlled by air-conditioner. The temperature difference between the thermostat room of the both sides of the test wall was below $20^{\circ} \mathrm{C}$. The measuring time was enough to make the thermal surroundings of the test wall was stable.

The thermal resistance and heat transfer coefficient of the test wall can be gained by the Equations (1) and (2) [11]. 


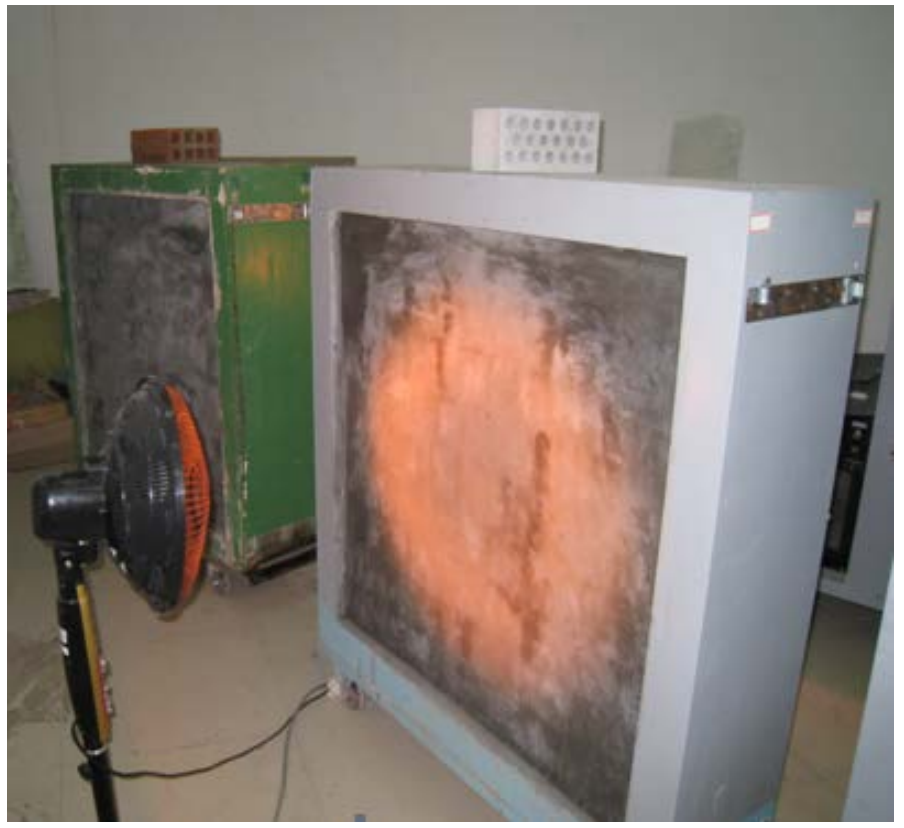

Figure 3. The test wall dried by warmer.

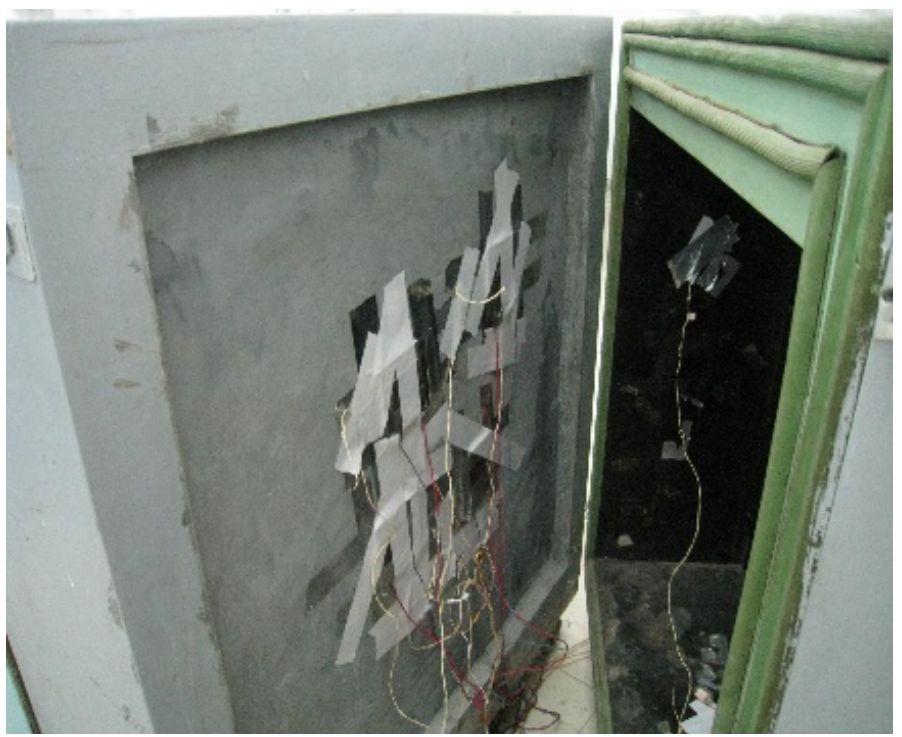

Figure 4. The pasted sensors.

$$
\begin{gathered}
R=\frac{T_{2}-T_{1}}{E \times C} \\
K=\frac{1}{R_{i}+R+R_{e}}
\end{gathered}
$$

where, $R$ is thermal resistance $\left[\left(\mathrm{m}^{2} \cdot \mathrm{K}\right) / \mathrm{W}\right], K$ is heat transfer coefficient $\left[\mathrm{W} /\left(\mathrm{m}^{2} \cdot \mathrm{K}\right)\right], T_{2}$ is the temperature of the high temperature thermostat room $[\mathrm{K}], T_{1}$ is the temperature of the low temperature thermostat room $[\mathrm{K}], E$ is the recording data of the heat flux meter $[\mathrm{mV}], C$ is the probe coefficient of the heat flux meter $\left[\mathrm{W} /\left(\mathrm{m}^{2} \cdot \mathrm{mv}\right)\right], \quad R_{i}$ is the surface thermal resistance of the interior 
face of the test wall $\left[\left(\mathrm{m}^{2} \cdot \mathrm{K}\right) / \mathrm{W}\right], R_{e}$ is the surface thermal resistance of the exterior face of the test wall $\left[\left(\mathrm{m}^{2} \cdot \mathrm{K}\right) / \mathrm{W}\right]$.

All the experiments were conduct in the Building Physical Environment Laboratory of the Civil Engineering Testing Center of Zhejiang University. The both sides of all the test walls were wiped by $10 \mathrm{~mm}$ cement mortar, whose dry density is $1800 \mathrm{~kg} / \mathrm{m}^{3}$ and thermal conductivity is $0.93 \mathrm{~W} /(\mathrm{m} \cdot \mathrm{K})$.

Firstly, four kinds of shale sintered hollow brick were measured, which have the character as shown in Table 1 . The dimension values with ${ }^{*}$ is the thickness of the test wall, however, the total thickness of the test wall should account for the $20 \mathrm{~mm}$ cement mortar. The pictures of the real products and the sectional views of the four kinds of shale sintered hollow brick were shown in Figure 5.
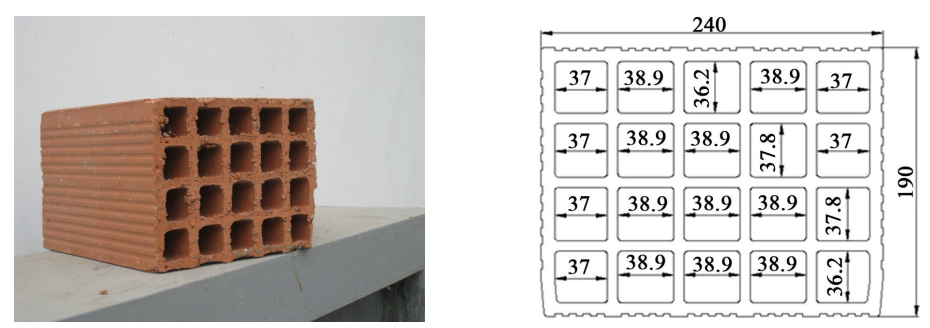

(1)
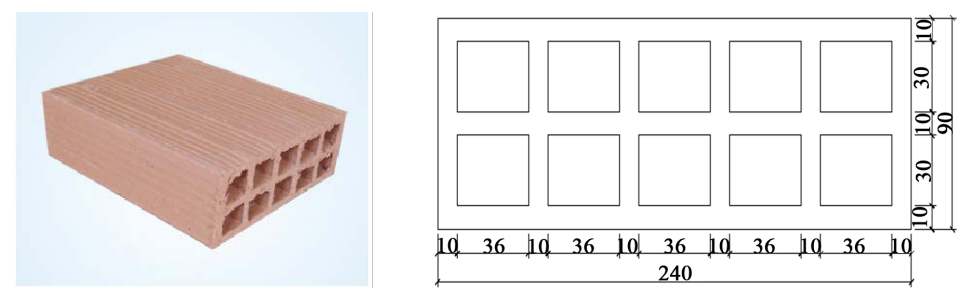

(2)
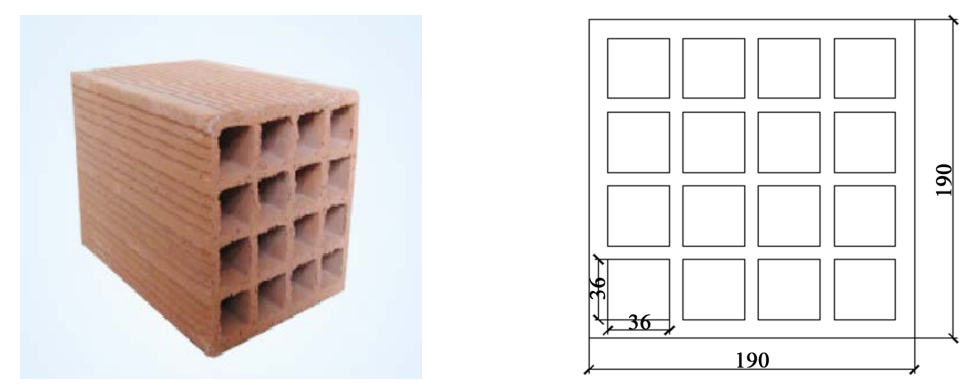

(3)
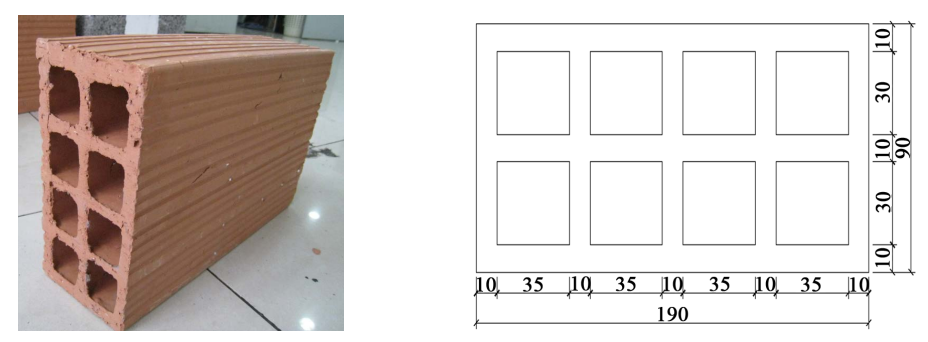

(4)

Figure 5. The pictures of the real products and the sectional views of the four kinds of shale sintered hollow brick. 
Table 1. The character of the four kinds of shale sintered hollow brick.

\begin{tabular}{ccccc}
\hline Numbers & Dimension $[\mathrm{mm}]$ & Density $\left[\mathrm{kg} / \mathrm{m}^{3}\right]$ & Porosity $[\%]$ & Specific heat $[\mathrm{KJ} /(\mathrm{kg} \cdot \mathrm{K})]$ \\
\hline (1) & $290 \times 240^{*} \times 190$ & 775 & 61.9 & 1.05 \\
(2) & $290 \times 240^{*} \times 90$ & 887 & 50 & 1.05 \\
(3) & $290 \times 190^{*} \times 190$ & 814 & 57.4 & 1.05 \\
(4) & $290 \times 190^{*} \times 90$ & 947 & 49.1 & 1.05 \\
\hline
\end{tabular}

The measuring results in Table 2 illustrated that the thermal character of the shale sintered hollow brick are varied from dimension and porosity. The reason is: the quantity of the air in the brick is more, the thermal performance is better, because of air is a thermal insulation material with a small thermal conductivity.

There are some methods to improve the thermal performance of the shale sintered hollow brick, such as increasing porosity, increasing the holes in the hollow brick, more reasonable hole arrangement, decreasing the hole wall thickness and filling the holes with thermal insulation material, etc. For further testing, the shale sintered hollow brick with dimension of $290 \mathrm{~mm} \times 240 \mathrm{~mm} \times$ $190 \mathrm{~mm}$ were filled with insulation material, that is expanded polystyrene panel (EPS), by different means, as shown in Figure 6.

The measuring results of different means of filling the holes with EPS are illustrated in Table 3. The Table shows that when the hole filled with heat insulation material, the thermal resistance can be significantly improved and the equivalent thermal conductivity significantly decreased, $0.154-0.160 \mathrm{~W} /(\mathrm{m} \cdot \mathrm{K})$ smaller than without insulation material. Among the four means, mean (3) and (4) are more efficient than other means in enhancing the thermal performance of the shale sintered hollow brick.

Besides, the shale sintered hollow brick after increasing the holes and rationalizing the hole arrangement (Figure 7) were also measured. The physical properties of the improved designing brick are present in Table 4.

The measuring results of the improved designing brick are shown in Table 5. The thermal performance of the brick can be improved when the hole number in the brick is more and the arrangement of the holes is more rational. The reason is that the rate of the air in the brick, which is an insulating material, become bigger after improved designing. The method of improved holes designing is easier than filling the holes with insulation materials. Therefore, it is most commonly used in the practice.

The shale sintered hollow brick can be used abundantly in the wall without load on account of its good thermal performance.

Secondly, two kinds of sand autoclaved aerated concrete block were used to test the thermal performance. The measuring results are shown in Table 6. The density of the sand autoclaved aerated concrete block is low and the thermal conductivity is small. Besides, the sand autoclaved aerated concrete block is safe, convenient in construction, economic and sound insulation when used in the building. Therefore, it is necessary to research further the performance of the sand autoclaved aerated concrete block. 
Table 2. The measuring results of the four kinds of shale sintered hollow brick.

\begin{tabular}{cccccc}
\hline Numbers & $\begin{array}{c}\text { Dimension } \\
{[\mathrm{mm}]}\end{array}$ & $\begin{array}{c}\text { Thermal } \\
\text { resistance } \\
{\left[\left(\mathrm{m}^{2} \cdot \mathrm{K}\right) / \mathrm{W}\right]}\end{array}$ & $\begin{array}{c}\text { Total thermal } \\
\text { resistance } \\
{\left[\left(\mathrm{m}^{2} \cdot \mathrm{K}\right) / \mathrm{W}\right]}\end{array}$ & $\begin{array}{c}\text { Heat transfer } \\
\text { coefficient } \\
{\left[\mathrm{W} /\left(\mathrm{m}^{2} \cdot \mathrm{K}\right)\right]}\end{array}$ & $\begin{array}{c}\text { Equivalent thermal } \\
\text { conductivity } \\
{[\mathrm{W} /(\mathrm{m} \cdot \mathrm{K})]}\end{array}$ \\
\hline (1) & $290 \times 240^{*} \times 190$ & 0.663 & 0.813 & 1.23 & 0.374 \\
(2) & $290 \times 240^{*} \times 90$ & 0.640 & 0.790 & 1.27 & 0.389 \\
(3) & $290 \times 190^{*} \times 190$ & 0.559 & 0.709 & 1.41 & 0.354 \\
(4) & $290 \times 190^{*} \times 90$ & 0.520 & 0.670 & 1.49 & 0.382 \\
\hline
\end{tabular}

Table 3. The measuring results of different means of filling the holes with EPS.

\begin{tabular}{cccccc}
\hline Means & $\begin{array}{c}\text { Apparent } \\
\text { density } \\
{\left[\mathrm{kg} / \mathrm{m}^{3}\right]}\end{array}$ & $\begin{array}{c}\text { Thermal } \\
\text { resistance } \\
{\left[\left(\mathrm{m}^{2} \cdot \mathrm{K}\right) / \mathrm{W}\right]}\end{array}$ & $\begin{array}{c}\text { Total thermal } \\
\text { resistance } \\
{\left[\left(\mathrm{m}^{2} \cdot \mathrm{K}\right) / \mathrm{W}\right]}\end{array}$ & $\begin{array}{c}\text { Heat transfer } \\
\text { coefficient } \\
{\left[\mathrm{W} /\left(\mathrm{m}^{2} \cdot \mathrm{K}\right)\right]}\end{array}$ & $\begin{array}{c}\text { Equivalent thermal } \\
\text { conductivity } \\
{[\mathrm{W} /(\mathrm{m} \cdot \mathrm{K})]}\end{array}$ \\
\hline (1) & 756 & 0.707 & 0.857 & 1.17 & 0.350 \\
(2) & 781 & 0.862 & 1.012 & 0.99 & 0.286 \\
(3) & 787 & 1.110 & 1.260 & 0.79 & 0.220 \\
(4) & 791 & 1.146 & 1.296 & 0.77 & 0.214 \\
\hline
\end{tabular}

Table 4. The character of the three kinds of shale sintered hollow brick after improved designing.

\begin{tabular}{ccccc}
\hline Numbers & Dimension $[\mathrm{mm}]$ & Density $\left[\mathrm{kg} / \mathrm{m}^{3}\right]$ & Porosity $[\%]$ & $\begin{array}{c}\text { Specific heat } \\
{[\mathrm{KJ} /(\mathrm{kg} \cdot \mathrm{K})]}\end{array}$ \\
\hline (1) & $290 \times 240^{*} \times 190$ & 959 & 52 & 1.05 \\
(2) & $290 \times 240^{*} \times 90$ & 801 & 60 & 1.05 \\
(3) & $290 \times 240^{*} \times 190$ & 852 & 50 & 1.05 \\
\hline
\end{tabular}

Table 5. The measuring results of the three kinds of shale sintered hollow brick after improved designing.

\begin{tabular}{ccccc}
\hline $\begin{array}{c}\text { Improved } \\
\text { designing }\end{array}$ & $\begin{array}{c}\text { Thermal } \\
\text { resistance } \\
{\left[\left(\mathrm{m}^{2} \cdot \mathrm{K}\right) / \mathrm{W}\right]}\end{array}$ & $\begin{array}{c}\text { Total thermal } \\
\text { resistance } \\
{\left[\left(\mathrm{m}^{2} \cdot \mathrm{K}\right) / \mathrm{W}\right]}\end{array}$ & $\begin{array}{c}\text { Heat transfer } \\
\text { coefficient } \\
{\left[\mathrm{W} /\left(\mathrm{m}^{2} \cdot \mathrm{K}\right)\right]}\end{array}$ & $\begin{array}{c}\text { Equivalent thermal } \\
\text { conductivity } \\
{[\mathrm{W} /(\mathrm{m} \cdot \mathrm{K})]}\end{array}$ \\
\hline (1) & 0.696 & 0.846 & 1.18 & 0.356 \\
(2) & 0.883 & 1.033 & 0.97 & 0.280 \\
(3) & 0.877 & 1.027 & 0.97 & 0.281 \\
\hline
\end{tabular}

Table 6. The measuring results of the two kinds of sand autoclaved aerated concrete block

\begin{tabular}{ccccccc}
\hline Numbers & Dimension $[\mathrm{mm}]$ & $\begin{array}{c}\text { Density } \\
{\left[\mathrm{kg} / \mathrm{m}^{3}\right]}\end{array}$ & $\begin{array}{c}\text { Thermal } \\
\text { resistance } \\
{\left[\left(\mathrm{m}^{2} \cdot \mathrm{K}\right) / \mathrm{W}\right]}\end{array}$ & $\begin{array}{c}\text { Total thermal } \\
\text { resistance } \\
{\left[\left(\mathrm{m}^{2} \cdot \mathrm{K}\right) / \mathrm{W}\right]}\end{array}$ & $\begin{array}{c}\text { Heat transfer } \\
\text { coefficient } \\
{\left[\mathrm{W} /\left(\mathrm{m}^{2} \cdot \mathrm{K}\right)\right]}\end{array}$ & $\begin{array}{c}\text { Equivalent } \\
\text { thermal } \\
\text { conductivity } \\
{[\mathrm{W} /(\mathrm{m} \cdot \mathrm{K})]}\end{array}$ \\
\hline (1) & $600 \times 250 \times 200^{*}$ & 413 & 1.285 & 1.435 & 0.697 & 0.156 \\
(2) & $600 \times 250 \times 200^{*}$ & 563 & 1.064 & 1.214 & 0.824 & 0.188 \\
\hline
\end{tabular}



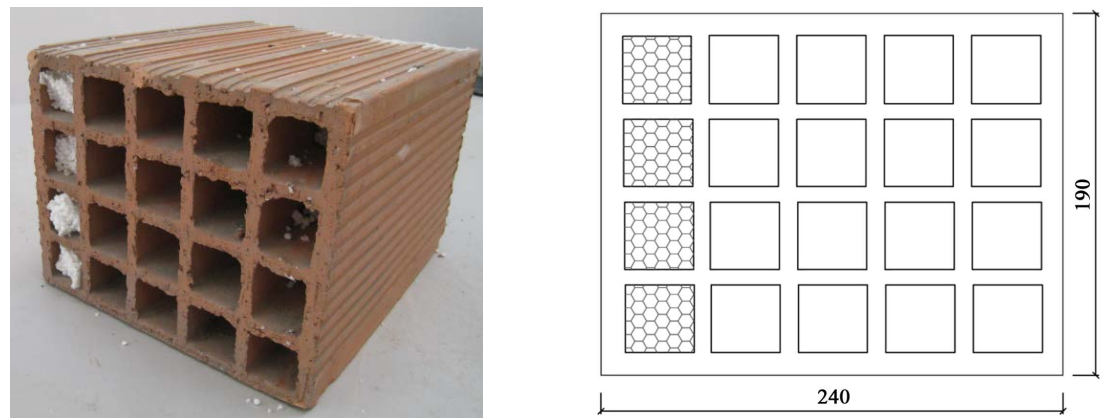

(1)
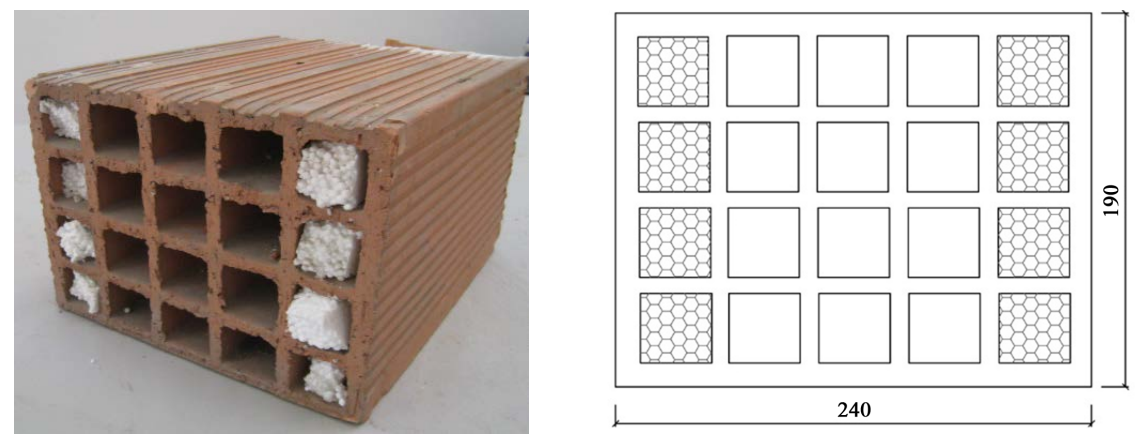

(2)
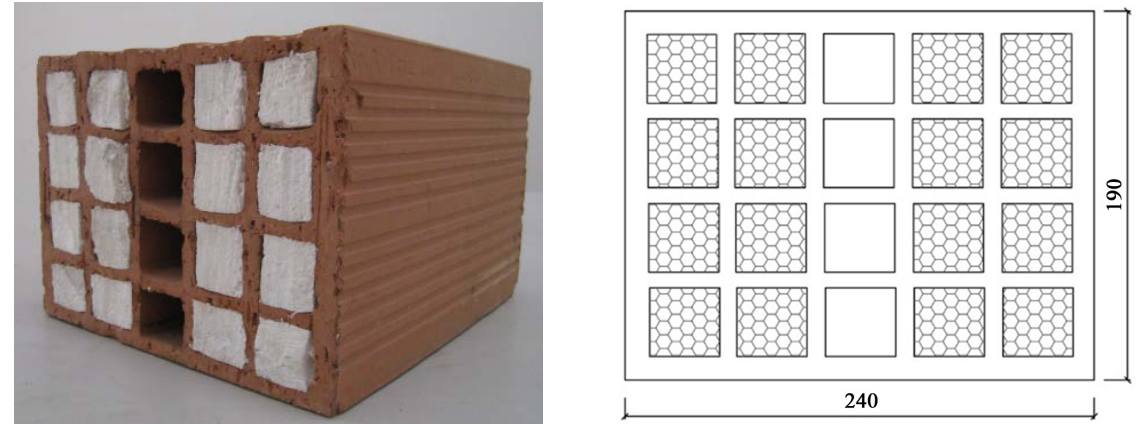

(3)
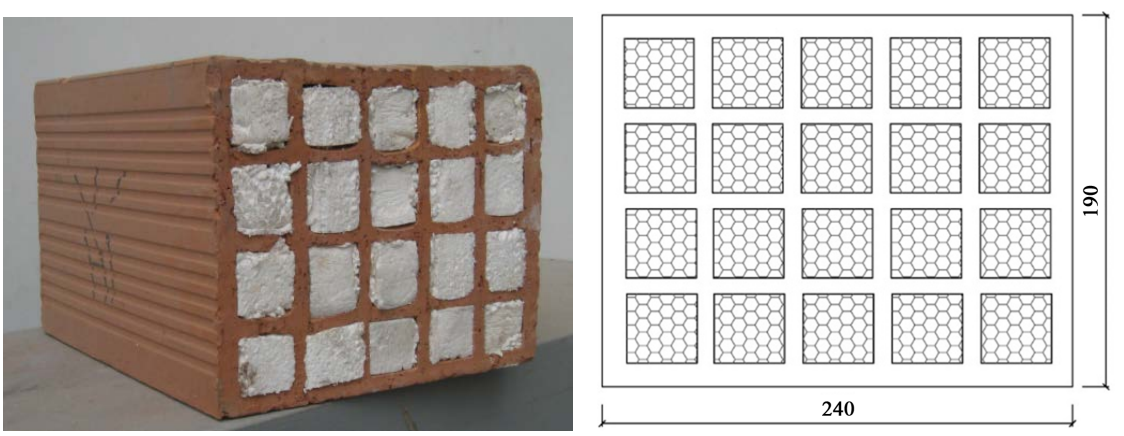

(4)

Figure 6. Different means of filling the holes with EPS.

Thirdly, the testing for two kinds of shale sintered porous brick (Figure 8) were carried out. From the results in Table 7, we can know the thermal performance of the two kinds of shale sintered porous brick is good as an insulation material of the wall in building. 

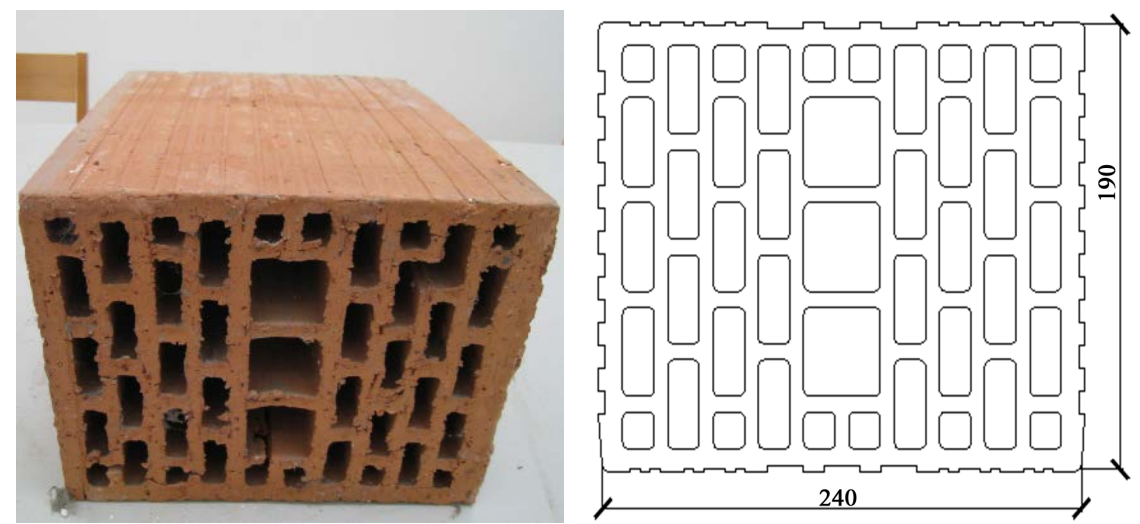

(1)
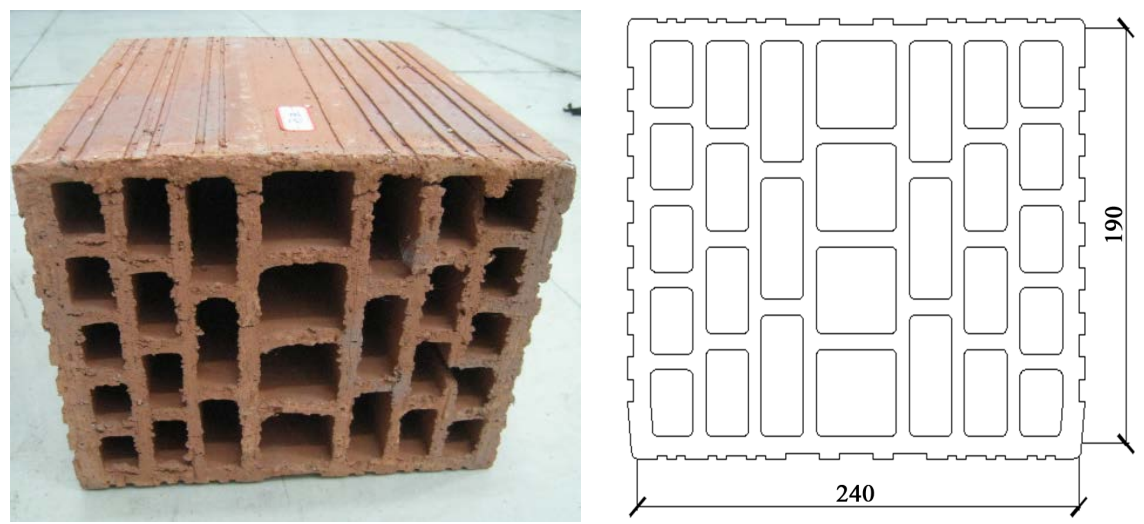

(2)
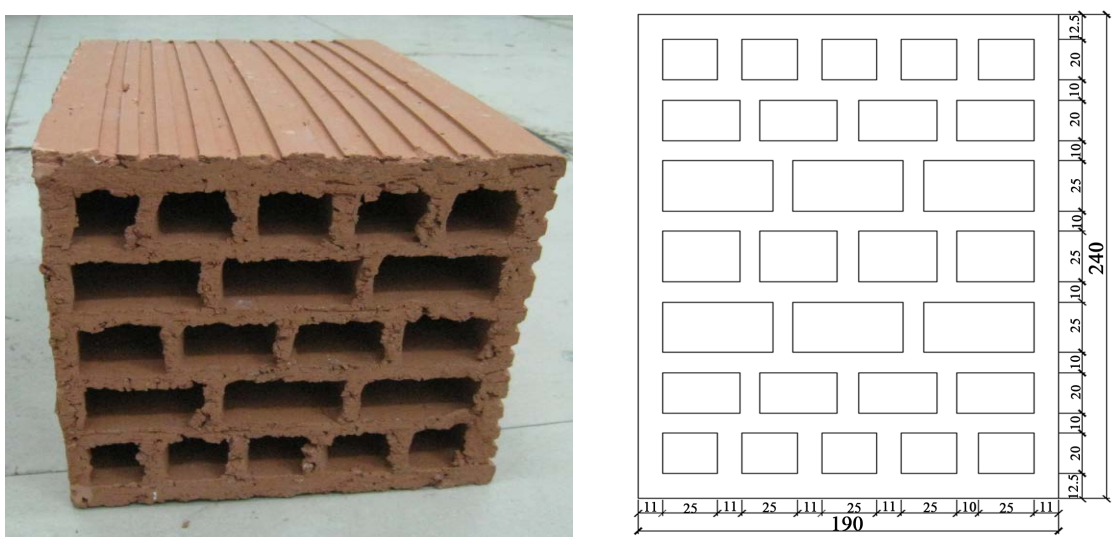

(3)

Figure 7. The shale sintered hollow brick after increasing the holes and rationalizing the hole arrangement.

Table 7. The measuring results of the two kinds of shale sintered porous brick.

\begin{tabular}{|c|c|c|c|c|c|c|c|}
\hline Numbers & Dimension $[\mathrm{mm}]$ & $\begin{array}{l}\text { Density } \\
{\left[\mathrm{kg} / \mathrm{m}^{3}\right]}\end{array}$ & $\begin{array}{c}\text { Porosity } \\
{[\%]}\end{array}$ & $\begin{array}{l}\text { Thermal } \\
\text { resistance } \\
{\left[\left(\mathrm{m}^{2} \cdot \mathrm{K}\right) / \mathrm{W}\right]}\end{array}$ & $\begin{array}{c}\text { Total } \\
\text { thermal } \\
\text { resistance } \\
{\left[\left(\mathrm{m}^{2} \cdot \mathrm{K}\right) / \mathrm{W}\right]}\end{array}$ & $\begin{array}{c}\text { Heat } \\
\text { transfer } \\
\text { coefficient } \\
{\left[\mathrm{W} /\left(\mathrm{m}^{2} \cdot \mathrm{K}\right)\right]}\end{array}$ & $\begin{array}{c}\text { Equivalent } \\
\text { thermal } \\
\text { conductivity } \\
{[\mathrm{W} /(\mathrm{m} \cdot \mathrm{K})]}\end{array}$ \\
\hline (1) & $240^{*} \times 115 \times 90$ & 1230 & 34.3 & 0.556 & 0.706 & 1.42 & 0.449 \\
\hline (2) & $240^{*} \times 240 \times 115$ & 887 & 45.7 & 0.553 & 0.683 & 1.46 & 0.470 \\
\hline
\end{tabular}



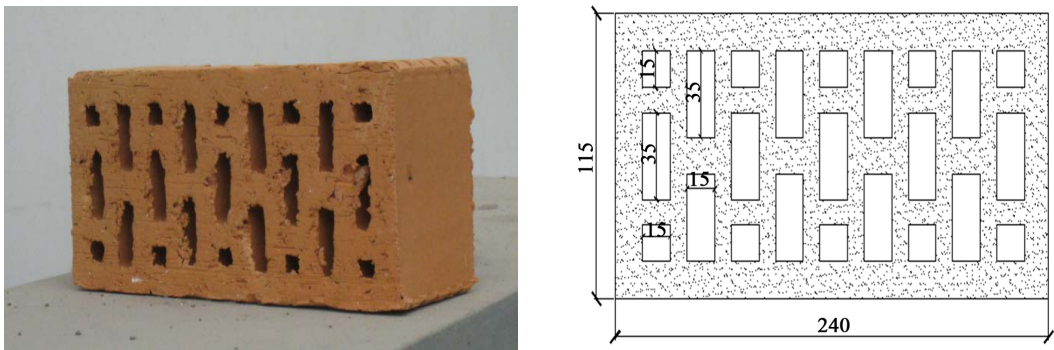

(1)
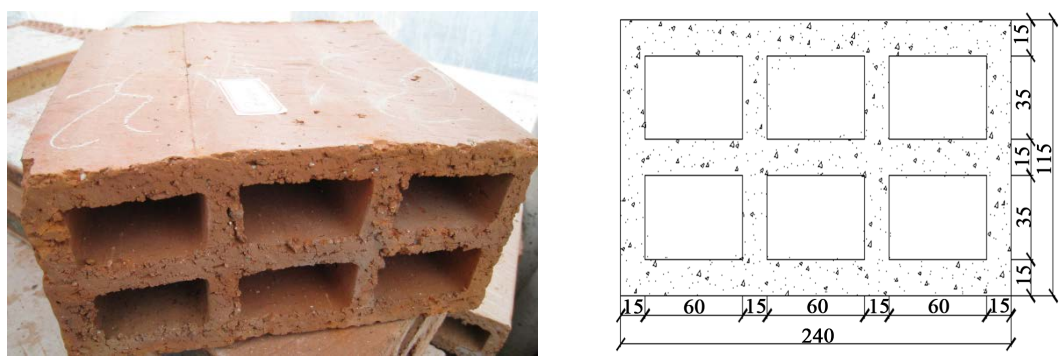

(2)

Figure 8. The pictures of the real products and the sectional views of the two kinds of shale sintered porous brick.

Commonly, the thermal performance of the shale sintered porous brick can be enhanced by means of changing the shape to make it modular, reducing the thickness of the hole wall, filling the holes with insulation material and change the thermal conductivity of the raw material of the brick.

Two kinds of shale sintered porous brick after modularizing (Figure 9) were test and the properties and results are shown in Table 8. The thermal performance of the brick can be improved by modularizing. Especially the kind (1), not only the thermal resistance is bigger than the not-modularizing, which is 0.556 $\left(\mathrm{m}^{2} \cdot \mathrm{K}\right) / \mathrm{W}$ but also the density is smaller and the porosity is bigger.

Besides, two kinds of shale sintered porous brick with insulation material in the raw material were also test. The kind (1) was added sawdust and the kind (2) was added sawdust and gangue (Figure 10). The results in Table 9 show that the thermal performance is improved obviously.

When filling the holes of the shale sintered porous brick with EPS (expanded polystyrene panel), as shown in Figure 11, the thermal performance is also improved obviously (Table 10).

Fourthly, three kinds of sintering gangue porous brick (Figure 12) were measured and the results are present in Table 11. The kind (2) and (3) is modularized. As shown in the table, the thermal performance is good. Besides, the modularizing sintering gangue porous brick can be used in the wall with thickness of $240 \mathrm{~mm}$ and $190 \mathrm{~mm}$, which is conformed to the habit of the architectural design and construction.

Fifthly, three kinds of sintering heat preservation brick (Figure 13) were test and the measuring results are shown in Table 12. The thermal performance of the sintering heat preservation brick is well and the density is small. 

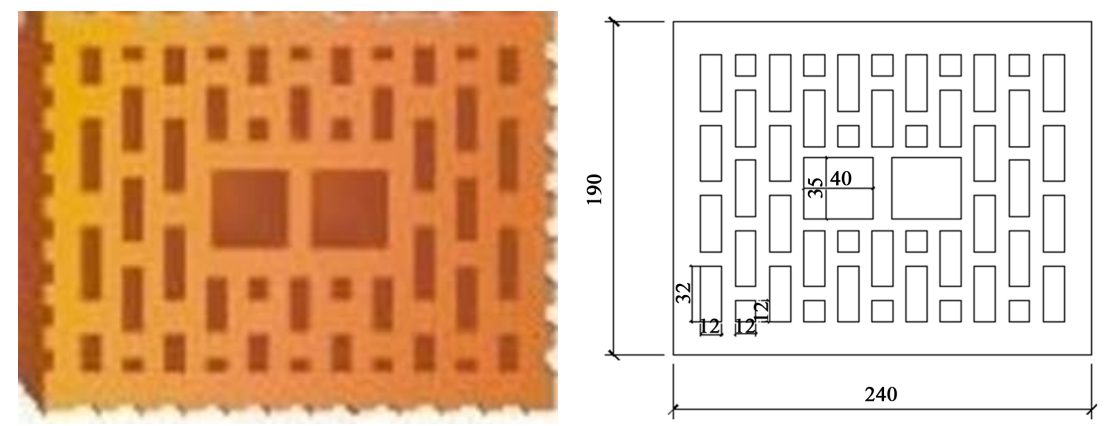

(1)
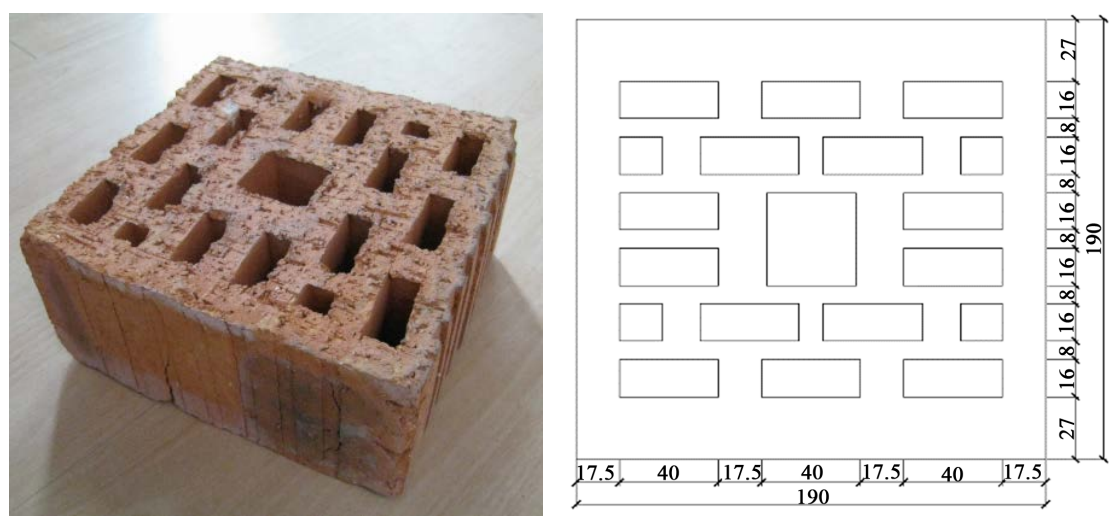

(2)

Figure 9. The pictures of the real products and the sectional views of the two kinds of modularizing shale sintered porous brick.
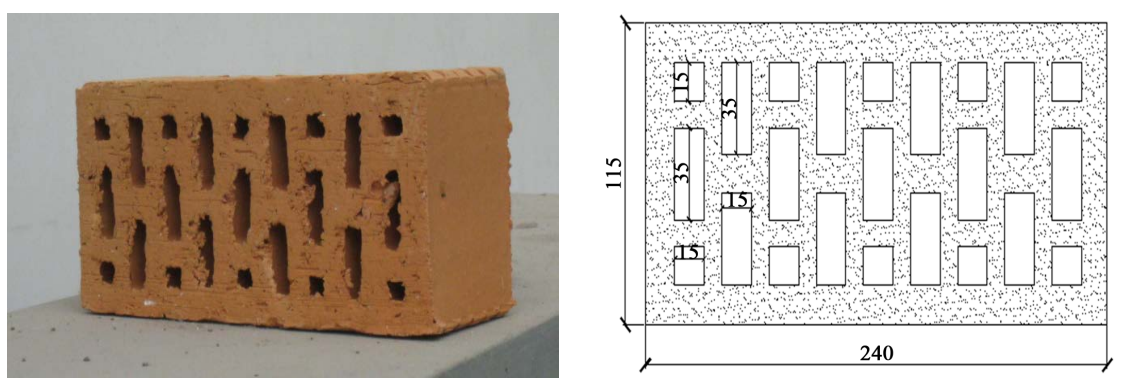

(1)
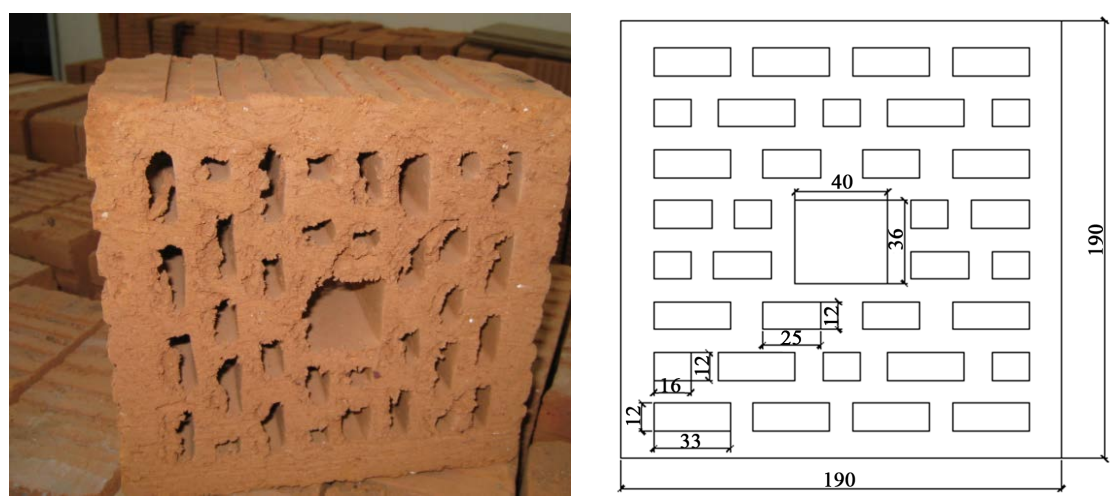

(2)

Figure 10. The pictures of the real products and the sectional views of the two kinds of shale sintered porous brick with adding insulation material. 

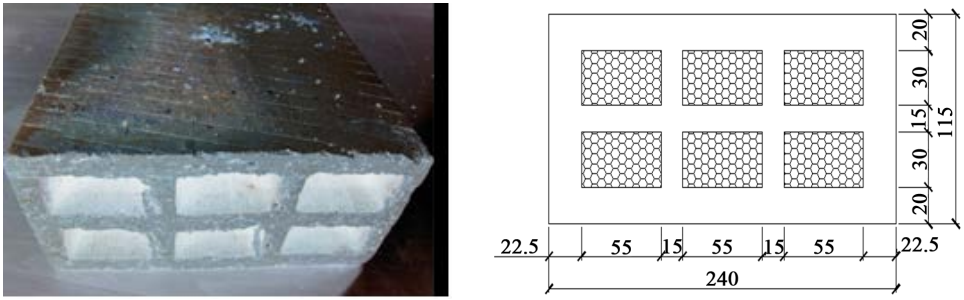

Figure 11. The pictures of the real products and the sectional views of the shale sintered porous brick with filling EPS in the holes.
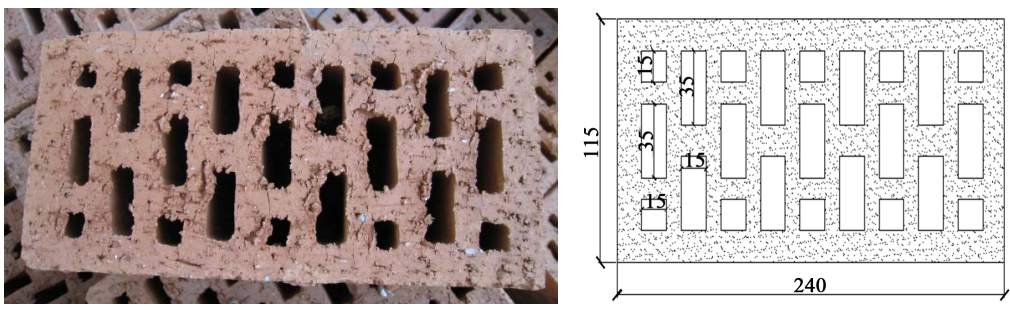

(1)
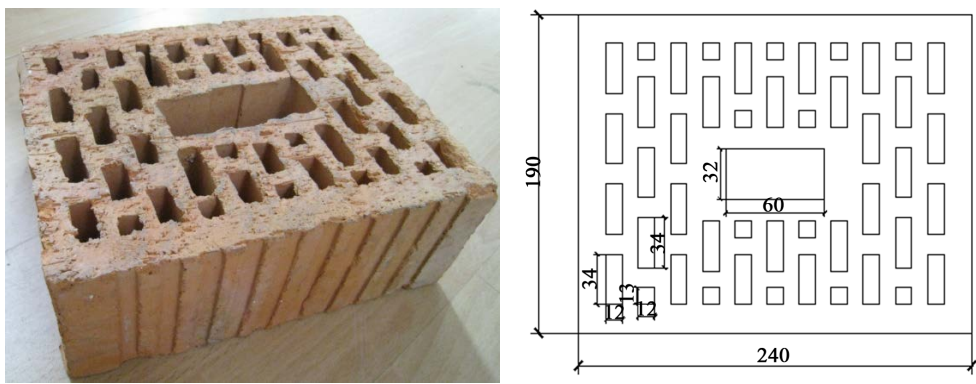

(2)
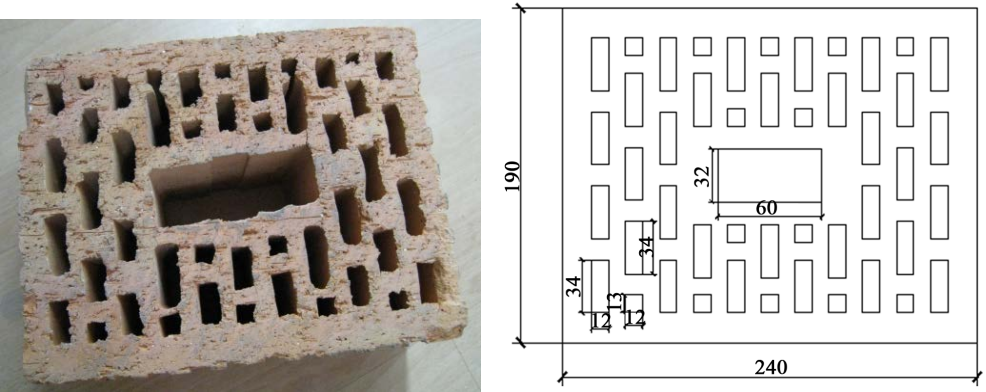

(3)

Figure 12. The pictures of the real products and the sectional views of the three kinds of sintering gangue porous brick.

Table 8. The measuring results of the two kinds of modularizing shale sintered porous brick.

\begin{tabular}{cccccccc}
\hline Numbers & $\begin{array}{c}\text { Dimension } \\
{[\mathrm{mm}]}\end{array}$ & $\begin{array}{c}\text { Density Porosity } \\
{\left[\mathrm{kg} / \mathrm{m}^{3}\right]}\end{array}$ & $\begin{array}{c}\text { Thermal } \\
{[\%]}\end{array}$ & $\begin{array}{c}\text { Total } \\
\text { resistance } \\
{\left[\left(\mathrm{m}^{2} \cdot \mathrm{K}\right) / \mathrm{W}\right]}\end{array}$ & $\begin{array}{c}\text { Heat } \\
\text { resistance } \\
{\left[\left(\mathrm{m}^{2} \cdot \mathrm{K}\right) / \mathrm{W}\right]}\end{array}$ & $\begin{array}{c}\text { Equivalent } \\
\text { transfer } \\
\text { coefficient } \\
{\left[\mathrm{W} /\left(\mathrm{m}^{2} \cdot \mathrm{K}\right)\right]}\end{array}$ & $\begin{array}{c}\text { conductivity } \\
{[\mathrm{W} /(\mathrm{m} \cdot \mathrm{K})]}\end{array}$ \\
\hline (1) & $240^{*} \times 190 \times 90$ & 1087 & 37.5 & 0.610 & 0.760 & 1.32 & 0.410 \\
(2) & $190^{*} \times 190 \times 90$ & 1402 & 32.0 & 0.550 & 0.700 & 1.43 & 0.375 \\
\hline
\end{tabular}



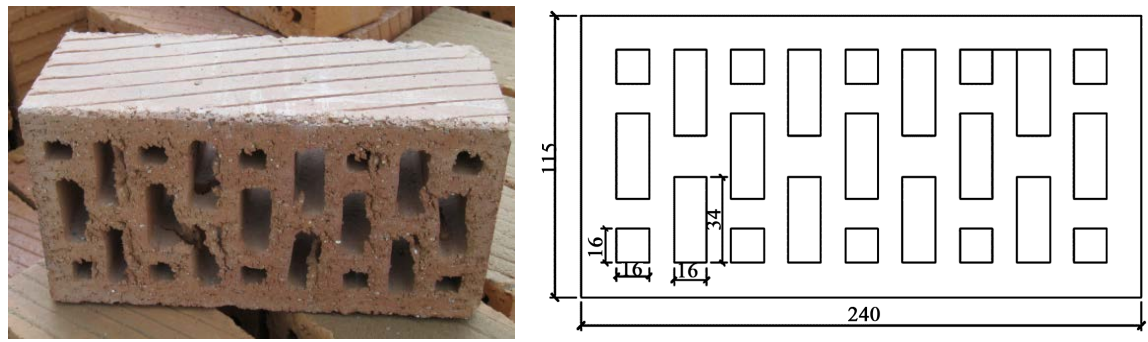

(1)
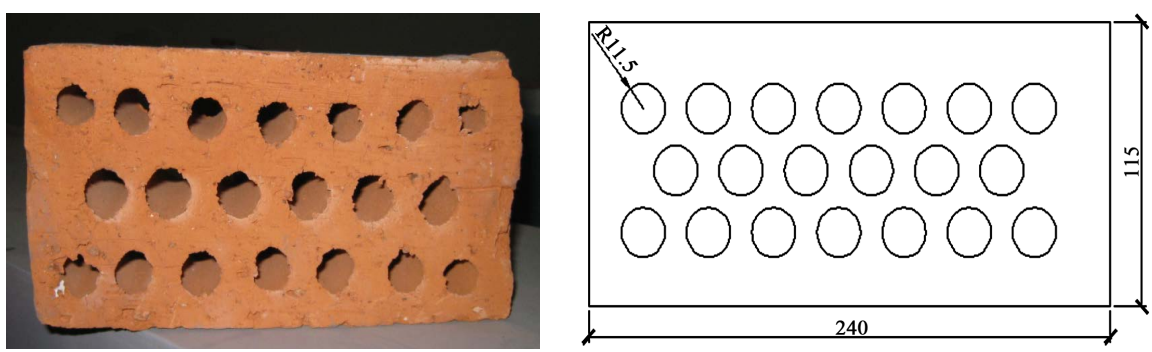

(2)
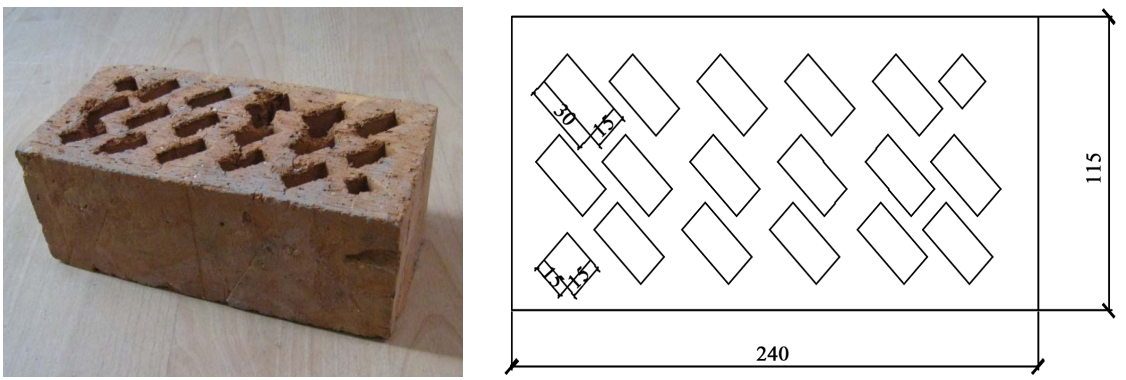

(3)

Figure 13. The pictures of the real products and the sectional views of the three kinds of sintering heat preservation brick.

Table 9. The measuring results of the two kinds of shale sintered porous brick with adding insulation material.

\begin{tabular}{cccccccc}
\hline Numbers & $\begin{array}{c}\text { Dimension } \\
{[\mathrm{mm}]}\end{array}$ & $\begin{array}{c}\text { Density } \\
{\left[\mathrm{kg} / \mathrm{m}^{3}\right]}\end{array}$ & $\begin{array}{c}\text { Porosity }] \\
{[\%}\end{array}$ & $\begin{array}{c}\text { Thermal } \\
\text { resistance } \\
{\left[\left(\mathrm{m}^{2} \cdot \mathrm{K}\right) / \mathrm{W}\right]}\end{array}$ & $\begin{array}{c}\text { Total } \\
\text { thermal } \\
\text { resistance } \\
{\left[\left(\mathrm{m}^{2} \cdot \mathrm{K}\right) / \mathrm{W}\right]}\end{array}$ & $\begin{array}{c}\text { Heat } \\
\text { transfer } \\
\text { coefficient } \\
{\left[\mathrm{W} /\left(\mathrm{m}^{2} \cdot \mathrm{K}\right)\right]}\end{array}$ & $\begin{array}{c}\text { Equivalent } \\
\text { thermal } \\
\text { conductivity } \\
{[\mathrm{W} /(\mathrm{m} \cdot \mathrm{K})]}\end{array}$ \\
\hline (1) & $240^{*} \times 115 \times 90$ & 1041 & 33.5 & 0.774 & 0.924 & 1.08 & 0.320 \\
(2) & $190^{*} \times 190 \times 90$ & 1216 & 33.5 & 0.709 & 0.859 & 1.16 & 0.285 \\
\hline
\end{tabular}

Table 10. The measuring results of the shale sintered porous brick with filling EPS in the holes.

\begin{tabular}{|c|c|c|c|c|c|c|c|}
\hline Numbers & $\begin{array}{l}\text { Dimension } \\
{[\mathrm{mm}]}\end{array}$ & $\begin{array}{l}\text { Density } \\
{\left[\mathrm{kg} / \mathrm{m}^{3}\right]}\end{array}$ & $\begin{array}{c}\text { Porosity } \\
{[\%]}\end{array}$ & $\begin{array}{l}\text { Thermal } \\
\text { resistance } \\
{\left[\left(\mathrm{m}^{2} \cdot \mathrm{K}\right) / \mathrm{W}\right]}\end{array}$ & $\begin{array}{c}\text { Total } \\
\text { thermal } \\
\text { resistance } \\
{\left[\left(\mathrm{m}^{2} \cdot \mathrm{K}\right) / \mathrm{W}\right]}\end{array}$ & $\begin{array}{c}\text { Heat } \\
\text { transfer } \\
\text { coefficient } \\
{\left[\mathrm{W} /\left(\mathrm{m}^{2} \cdot \mathrm{K}\right)\right]}\end{array}$ & $\begin{array}{l}\text { Equivalent } \\
\text { thermal } \\
\text { conductivity } \\
{[\mathrm{W} /(\mathrm{m} \cdot \mathrm{K})]}\end{array}$ \\
\hline (1) & $240^{*} \times 240 \times 115$ & 1015 & 35.8 & 0.670 & 0.820 & 1.22 & 0.370 \\
\hline
\end{tabular}


Table 11. The measuring results of the three kinds of sintering gangue porous brick.

\begin{tabular}{cccccccc}
\hline Numbers & $\begin{array}{c}\text { Dimension } \\
{[\mathrm{mm}]}\end{array}$ & $\begin{array}{c}\text { Density Porosity } \\
{\left[\mathrm{kg} / \mathrm{m}^{3}\right]}\end{array}$ & $\begin{array}{c}\text { Thermal } \\
\text { resistance } \\
{\left[\left(\mathrm{m}^{2} \cdot \mathrm{K}\right) / \mathrm{W}\right]}\end{array}$ & $\begin{array}{c}\text { Total } \\
\text { thermal } \\
\text { resistance } \\
{\left[\left(\mathrm{m}^{2} \cdot \mathrm{K}\right) / \mathrm{W}\right]}\end{array}$ & $\begin{array}{c}\text { Heat } \\
\text { transfer } \\
\text { coefficient } \\
{\left[\mathrm{W} /\left(\mathrm{m}^{2} \cdot \mathrm{K}\right)\right]}\end{array}$ & $\begin{array}{c}\text { Equivalent } \\
\text { thermal }\end{array}$ \\
$\begin{array}{c}\text { conductivity } \\
{[\mathrm{W} /(\mathrm{m} \cdot \mathrm{K})]}\end{array}$ \\
\hline (1) & $240^{*} \times 115 \times 90$ & 1209 & 32.9 & 0.569 & 0.719 & 1.39 & 0.438 \\
(2) & $240^{*} \times 190 \times 90$ & 1223 & 33.4 & 0.610 & 0.760 & 1.32 & 0.410 \\
(3) & $240 \times 190^{*} \times 90$ & 1223 & 33.4 & 0.576 & 0.726 & 1.38 & 0.340 \\
\hline
\end{tabular}

Table 12. The measuring results of the three kinds of sintering heat preservation brick.

\begin{tabular}{cccccccc}
\hline Numbers & $\begin{array}{c}\text { Dimension } \\
{[\mathrm{mm}]}\end{array}$ & $\begin{array}{c}\text { Density Porosity } \\
{\left[\mathrm{kg} / \mathrm{m}^{3}\right]}\end{array}\left[\begin{array}{c}\text { Thermal } \\
\text { resistance } \\
{\left[\left(\mathrm{m}^{2} \cdot \mathrm{K}\right) / \mathrm{W}\right]}\end{array}\right.$ & $\begin{array}{c}\text { Total } \\
\text { thermal } \\
\text { resistance } \\
{\left[\left(\mathrm{m}^{2} \cdot \mathrm{K}\right) / \mathrm{W}\right]}\end{array}$ & $\begin{array}{c}\text { Heat } \\
\text { transfer } \\
\text { coefficient } \\
{\left[\mathrm{W} /\left(\mathrm{m}^{2} \cdot \mathrm{K}\right)\right]}\end{array}$ & $\begin{array}{c}\text { Equivalent } \\
\text { thermal } \\
\text { conductivity } \\
{[\mathrm{W} /(\mathrm{m} \cdot \mathrm{K})]}\end{array}$ \\
\hline (1) & $240^{*} \times 115 \times 90$ & 903 & 34.9 & 0.698 & 0.848 & 1.18 & 0.425 \\
(2) & $240^{*} \times 115 \times 90$ & 1011 & 30.1 & 0.560 & 0.710 & 1.41 & 0.440 \\
(3) & $240^{*} \times 115 \times 90$ & 1022 & 27.7 & 0.600 & 0.750 & 1.34 & 0.510 \\
\hline
\end{tabular}

Sixthly, three kinds of composite concrete porous brick with or without filling EPS (Figure 14) was test and the results are shown in Table 13, which indicates the thermal performance is well. After filling the holes with EPS, the thermal performance can be improved.

The conclusions of the indoor experiment researches of thermal physical Six kinds of common non-clay wall materials, that are shale sintered hollow brick, sand autoclaved aerated concrete block, shale sintered porous brick, sintering gangue porous brick, sintering heat preservation brick and composite concrete porous brick were test in the indoor experiment researches of thermal physical. The thermal performance, after some improved measures were taken, was also analyzed comparatively. The conclusions are as follows.

The density and the thermal conductivity of the six non-clay wall material are all smaller than the density and the thermal conductivity of the clay porous brick, which is $1400 \mathrm{~kg} / \mathrm{m}^{3}$ and $0.58 \mathrm{~W} /(\mathrm{m} \cdot \mathrm{K})$, respectively. Besides, the porosity of the six non-clay wall material are all bigger than the porosity of the clay porous brick, which is about $30 \%$. Therefore, the non-clay brick can be used as new wall material of energy efficient.

Commonly, the thermal performance of the non-clay brick can be improved obviously through the rational arrangement of the holes such as modularizing the holes, filling the holes with insulation material such as EPS and adding insulation material in the raw material. Think of filling the holes with EPS is not appropriate for mass production, rational arrangement of the holes and adding insulation material become the feasible means to improve the thermal performance further of the non-clay bricks.

Comparing comprehensively the results mentioned above, two materials, shale sintered hollow brick after increasing the holes and rationalizing the hole 

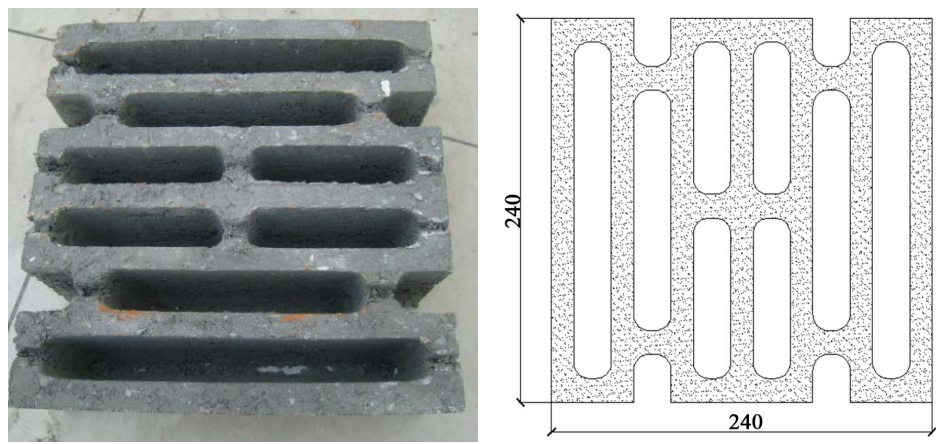

(1)
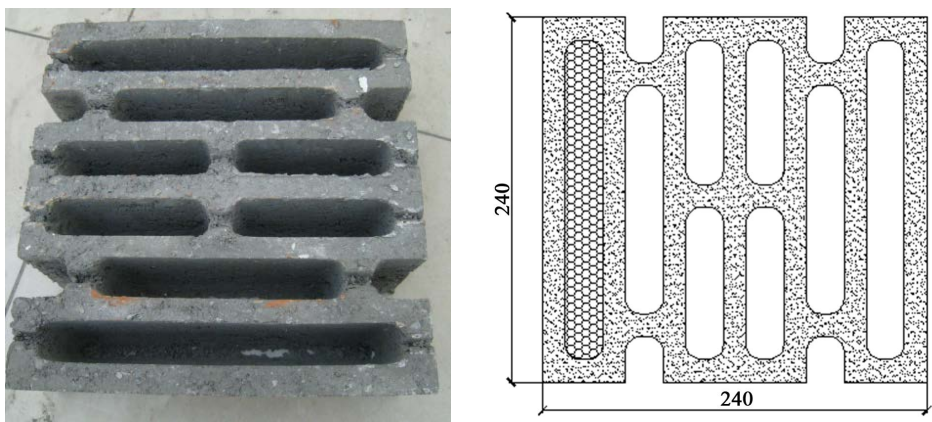

(2)
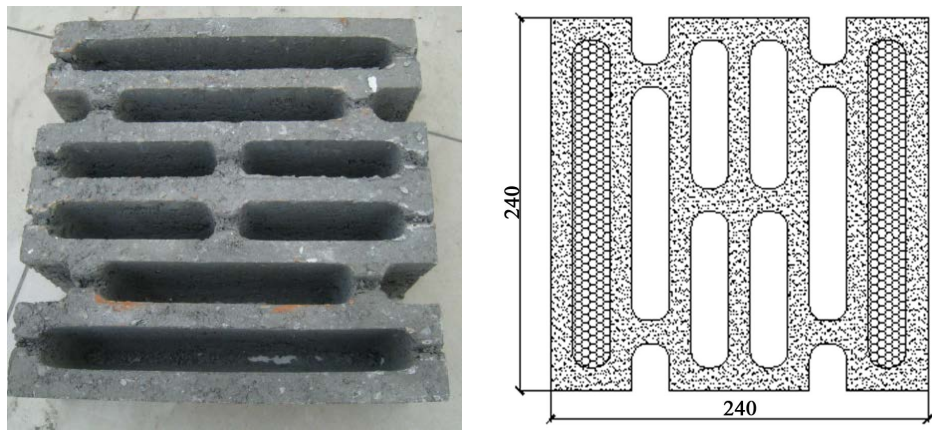

(3)

Figure 14. The pictures of the real products and the sectional views of the composite concrete porous brick with or without filling EPS.

Table 13. The measuring results of the composite concrete porous brick with or without filling EPS.

\begin{tabular}{cccccccc}
\hline Numbers & $\begin{array}{c}\text { Dimension } \\
{[\mathrm{mm}]}\end{array}$ & $\begin{array}{c}\text { Density Porosity } \\
{\left[\mathrm{kg} / \mathrm{m}^{3}\right]}\end{array}$ & $\begin{array}{c}\text { Thermal } \\
\text { resistance } \\
{\left[\left(\mathrm{m}^{2} \cdot \mathrm{K}\right) / \mathrm{W}\right]}\end{array}$ & $\begin{array}{c}\text { Total } \\
\text { thermal } \\
\text { resistance } \\
{\left[\left(\mathrm{m}^{2} \cdot \mathrm{K}\right) / \mathrm{W}\right]}\end{array}$ & $\begin{array}{c}\text { Heat } \\
\text { transfer } \\
\text { coefficient } \\
{\left[\mathrm{W} /\left(\mathrm{m}^{2} \cdot \mathrm{K}\right)\right]}\end{array}$ & $\begin{array}{c}\text { Equivalent } \\
\text { thermal } \\
\text { conductivity } \\
{[\mathrm{W} /(\mathrm{m} \cdot \mathrm{K})]}\end{array}$ \\
\hline (1) & $240^{*} \times 240 \times 90$ & 1244 & 41.0 & 0.603 & 0.753 & 1.33 & 0.429 \\
(2) & $240^{*} \times 240 \times 90$ & 1245 & 41.0 & 0.642 & 0.792 & 1.26 & 0.401 \\
(3) & $240^{*} \times 240 \times 90$ & 1247 & 41.0 & 0.699 & 0.849 & 1.18 & 0.366 \\
\hline
\end{tabular}

arrangement (Table 14) and sand autoclaved aerated concrete block (Table 15) are recommended as the more proper material used in the insulation wall of building in the hot summer and cold winter area of China. 
Table 14. The properties of the shale sintered hollow brick after increasing the holes and rationalizing the hole arrangement.

\begin{tabular}{cccccccc}
\hline Numbers & $\begin{array}{c}\text { Dimension } \\
{[\mathrm{mm}]}\end{array}$ & $\begin{array}{c}\text { Density Porosity } \\
{\left[\mathrm{kg} / \mathrm{m}^{3}\right]}\end{array}\left[\begin{array}{c}\text { Thermal } \\
{\left[\begin{array}{c}\text { resistance } \\
{\left[\left(\mathrm{m}^{2} \cdot \mathrm{K}\right) / \mathrm{W}\right]}\end{array}\right.}\end{array}\right.$ & $\begin{array}{c}\text { Total } \\
\text { thermal } \\
\text { resistance } \\
{\left[\left(\mathrm{m}^{2} \cdot \mathrm{K}\right) / \mathrm{W}\right]}\end{array}$ & $\begin{array}{c}\text { Heat } \\
\text { transfer } \\
\text { coefficient } \\
{\left[\mathrm{W} /\left(\mathrm{m}^{2} \cdot \mathrm{K}\right)\right]}\end{array}$ & $\begin{array}{c}\text { Equivalent } \\
\text { thermal }\end{array}$ \\
{$\left[\begin{array}{c}\text { conductivity } \\
{[\mathrm{W} /(\mathrm{m} \cdot \mathrm{K})]}\end{array}\right.$} \\
\hline (2) & $290 \times 240^{*} \times 90$ & 801 & 60 & 0.883 & 1.033 & 0.97 & 0.280 \\
(3) & $290 \times 240^{*} \times 190$ & 852 & 50 & 0.877 & 1.027 & 0.97 & 0.281 \\
\hline
\end{tabular}

Table 15. The properties of the sand autoclaved aerated concrete block.

\begin{tabular}{ccccccc}
\hline Numbers & Dimension $[\mathrm{mm}]$ & $\begin{array}{c}\text { Density } \\
{\left[\mathrm{kg} / \mathrm{m}^{3}\right]}\end{array}$ & $\begin{array}{c}\text { Thermal } \\
\text { resistance } \\
{\left[\left(\mathrm{m}^{2} \cdot \mathrm{K}\right) / \mathrm{W}\right]}\end{array}$ & $\begin{array}{c}\text { Total } \\
\text { thermal } \\
\text { resistance } \\
{\left[\left(\mathrm{m}^{2} \cdot \mathrm{K}\right) / \mathrm{W}\right]}\end{array}$ & $\begin{array}{c}\text { Heat } \\
\text { transfer } \\
\text { coefficient } \\
{\left[\mathrm{W} /\left(\mathrm{m}^{2} \cdot \mathrm{K}\right)\right]}\end{array}$ & $\begin{array}{c}\text { Equivalent } \\
\text { thermal } \\
\text { conductivity } \\
{[\mathrm{W} /(\mathrm{m} \cdot \mathrm{K})]}\end{array}$ \\
\hline (1) & $600 \times 250 \times 200^{*}$ & 413 & 1.285 & 1.435 & 0.697 & 0.156 \\
(2) & $600 \times 250 \times 200^{*}$ & 563 & 1.064 & 1.214 & 0.824 & 0.188 \\
\hline
\end{tabular}

\section{The Building Energy Consumption Dynamic Calculation Using PKPM}

When the wall of a building adopts the insulation material, the thermal resistance of the wall can be improved obviously. However, the heat transfer through the column and girder, which are made of reinforced concrete commonly, is still big because of the heat conductivity of the column and girder is big. This is called heat bridge phenomenon. It is of vital importance to impede the heat transfer through the heat bridge for the sake of energy efficient of building. Usually, the heat transfer through the heat bridge can be reduced by painting insulation material such as insulation mortar. In order to analyze the energy consumption of the building using the non-clay brick mentioned above and insulation material on the heat bridge cooperatively, the dynamic calculations using PKPM, an energy consumption simulation tool developed by the China Academy of Building Research Shanghai Institute based on DOE-2, were carried out using the meteorological parameter of Hangzhou. On account of Hangzhou is a typical city of the hot summer and cold winter area of China, the conclusions can be applied to the most cities of the area.

The building model selected to dynamic simulate should be representative, so three kinds of common building forms in Hangzhou were employed. After some necessary simplification, which had little influence on thermal environment, the plans and the PKPM models of the three kinds of common building forms are present in Figure 15. The building profiles are present in Table 16.

The envelops constitution of the building in the PKPM are shown in Table 17. The shading coefficient of the windows is 0.83 . According to the limiting values in the Design Standard for Energy Efficiency of Residential Buildings of Zhejiang province of China and the Design Standard for Energy Efficiency of Public Buildings of Zhejiang province of China, the three kinds of typical buildings 

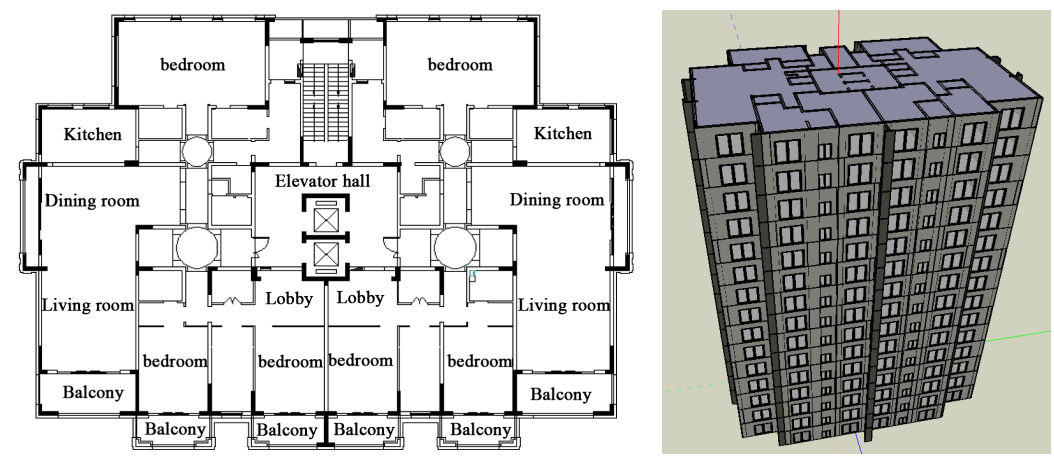

(1)
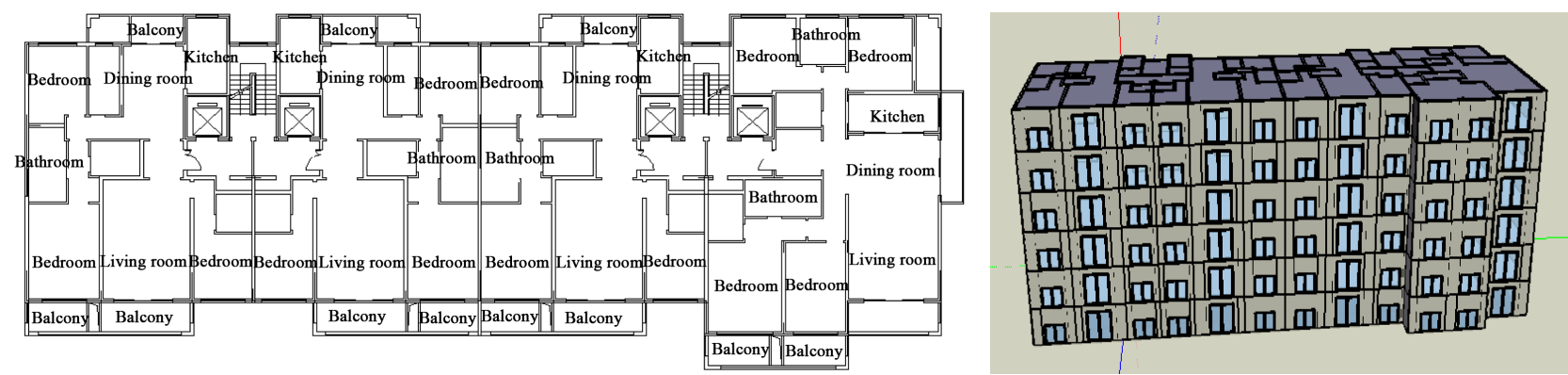

(2)
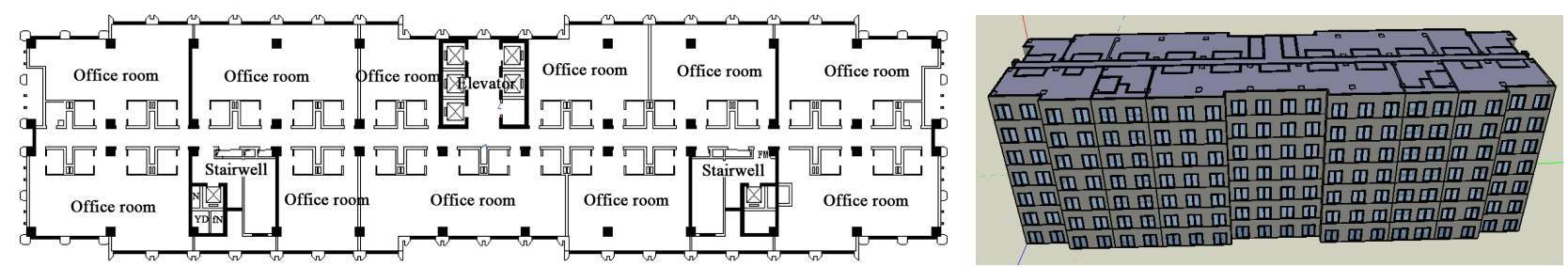

(3)

Figure 15. The plans and the PKPM models of the three kinds of typical buildings in Hangzhou.

Table 16. The building profiles of three kinds of typical buildings in Hangzhou.

\begin{tabular}{|c|c|c|c|c|}
\hline \multicolumn{2}{|l|}{ City } & \multicolumn{3}{|c|}{ Hangzhou, 30 degrees north latitude and 120 degrees east longitude } \\
\hline \multicolumn{2}{|l|}{ Climate zone } & \multicolumn{3}{|c|}{ Hot summer and cold winter } \\
\hline \multicolumn{2}{|l|}{ Building type } & Point block apartment & Stick block apartment & Office building \\
\hline \multicolumn{2}{|l|}{ Orientation } & South & South & South \\
\hline \multicolumn{2}{|l|}{ Structure type } & Frame & Frame & Frame \\
\hline \multicolumn{2}{|l|}{ Floors } & 15 & 6 & 7 \\
\hline \multicolumn{2}{|l|}{ Floor height $(\mathrm{mm})$} & 3000 & 3000 & 3750 \\
\hline \multicolumn{2}{|l|}{ Shape coefficient } & 0.21 & 0.23 & 0.16 \\
\hline \multirow{4}{*}{$\begin{array}{l}\text { The area rate of window to } \\
\text { wall }\end{array}$} & East & 0.30 & 0.21 & 0.05 \\
\hline & South & 0.35 & 0.34 & 0.36 \\
\hline & West & 0.30 & 0.05 & 0.05 \\
\hline & North & 0.30 & 0.34 & 0.36 \\
\hline \multicolumn{2}{|c|}{$\begin{array}{l}\text { The area of } \\
\text { air-conditioning }\left(\mathrm{m}^{2}\right)\end{array}$} & 7589.68 & 2755.17 & 9155.29 \\
\hline \multicolumn{2}{|c|}{ The area of non-air-conditioning $\left(\mathrm{m}^{2}\right)$} & 2354.22 & 1529.58 & 4842.14 \\
\hline
\end{tabular}


Table 17. The envelops constitution of the building in the PKPM.

\begin{tabular}{|c|c|c|}
\hline Names & Constitution & $\begin{array}{l}\text { Heat transfer } \\
\text { coefficient } \\
{\left[\mathrm{W} /\left(\mathrm{m}^{2} \cdot \mathrm{K}\right)\right]}\end{array}$ \\
\hline $\begin{array}{l}\text { Exterior } \\
\text { wall }\end{array}$ & $\begin{array}{l}\text { The main wall: } 20 \mathrm{~mm} \text { cement mortar }+240 \mathrm{~mm} \text { sand autoclaved } \\
\text { aerated concrete block }+20 \mathrm{~mm} \text { cement mortar } \\
\text { Heat bridge: } 5 \mathrm{~mm} \text { anti-crack mortar }+20 \mathrm{~mm} \text { inorganic insulation } \\
\text { mortar }+240 \mathrm{~mm} \text { reinforced concrete }+20 \mathrm{~mm} \text { cement mortar }\end{array}$ & 1.34 \\
\hline $\begin{array}{l}\text { Interior } \\
\text { wall }\end{array}$ & $\begin{array}{l}20 \mathrm{~mm} \text { cement mortar }+240 \mathrm{~mm} \text { sand autoclaved aerated } \\
\text { concrete block }+20 \mathrm{~mm} \text { cement mortar }\end{array}$ & 0.78 \\
\hline Roof & $\begin{array}{c}40 \mathrm{~mm} \text { fine aggregate concrete }+20 \mathrm{~mm} \text { cement mortar }+50 \mathrm{~mm} \\
\text { foam glass }+20 \mathrm{~mm} \text { cement mortar }+30 \mathrm{~mm} \text { light aggregate } \\
\text { concrete }+120 \mathrm{~mm} \text { reinforced concrete }\end{array}$ & 0.98 \\
\hline Ceiling & $20 \mathrm{~mm}$ cement mortar $+120 \mathrm{~mm}$ reinforced concrete & 2.92 \\
\hline Windows & $6 \mathrm{~mm}$ clear glass $+12 \mathrm{~mm}$ air $+6 \mathrm{~mm}$ clear glass & 3.4 \\
\hline Doors & Energy efficient doors & 2.77 \\
\hline
\end{tabular}

had a base case respectively. We can analyze the energy consumption difference between the base case and the new case (as shown in Table 17), whose envelops thermal performance are better than the limiting values [12].

The indoor calculation parameters of two kinds of apartments were set according to the Design Standard for Energy Efficiency of Residential Buildings of Zhejiang province of China. That is, the air-conditioning temperature of the bedroom and living room is $18^{\circ} \mathrm{C}$ for winter and $26^{\circ} \mathrm{C}$ for summer. The indoor ventilation coefficient is 1 rate/hour when the air-condition is operating. The indoor calculation parameters of the office building were set according to the Design Standard for Energy Efficiency of Public Buildings of Zhejiang province of China. That is, the air-conditioning temperature of the general office is $20^{\circ} \mathrm{C}$ for winter and $26^{\circ} \mathrm{C}$ for summer, the air-conditioning temperature of the others room is $18^{\circ} \mathrm{C}$ for winter and $26^{\circ} \mathrm{C}$ for summer. The people density of the general office and the others of the office building is $4 \mathrm{~m}^{2} /$ person and $5 \mathrm{~m}^{2} /$ person respectively [13]. The lighting is $11 \mathrm{~W} / \mathrm{m}^{2}$ and $5 \mathrm{~W} / \mathrm{m}^{2}$, respectively. The electric equipment is $20 \mathrm{~W} / \mathrm{m}^{2}$ and $5 \mathrm{~W} / \mathrm{m}^{2}$, respectively. The fresh air of the general office and the others rooms is $30 \mathrm{~m}^{3} /$ hour/person and $5 \mathrm{~m}^{3} /$ hour/person, respectively [14].

The energy consumption results of the three kinds of typical buildings and the base cases are shown in Table 18. The total energy consumption of the three new cases is all smaller than the base cases and the difference is $2.1 \%, 1.6 \%$ and $1.2 \%$, respectively. Because of the base cases are all satisfied with the needs of energy efficiency, the new cases can also satisfy the energy efficiency. Therefore, the sand autoclaved aerated concrete block should be used in the building wall as a new insulation material.

Besides, the energy consumptions were calculated when replacing the sand autoclaved aerated concrete block of the exterior wall by other non-clay material 
Table 18. The energy consumption results of the three kinds of typical buildings and the base cases.

\begin{tabular}{ccccccc}
\hline \multirow{2}{*}{ Energy type } & \multicolumn{2}{c}{ Point block apartment } & \multicolumn{2}{c}{ Stick block apartment } & \multicolumn{2}{c}{ Office building } \\
\cline { 2 - 7 } & New case & Base case & New case & Base case & New case & Base case \\
\hline $\begin{array}{c}\text { Total cooling } \\
\text { energy }\end{array}$ & 336,121 & 335,533 & 135,754 & 134,969 & 972,582 & 959,148 \\
$\begin{array}{c}\text { Cooling energy } \\
\text { per building area }\end{array}$ & 33.80 & 33.74 & 31.68 & 31.50 & 69.48 & 68.52 \\
$\begin{array}{c}\text { Total heating } \\
\text { energy }\end{array}$ & 217,020 & 229,597 & 93,165 & 97,725 & 483,755 & 514,465 \\
$\begin{array}{c}\text { Heating energy } \\
\text { per building area }\end{array}$ & 21.82 & 23.09 & 21.74 & 22.81 & 34.56 & 36.75 \\
$\begin{array}{c}\text { Total energy } \\
\begin{array}{c}\text { Total energy per } \\
\text { building area }\end{array}\end{array}$ & 553,141 & 565,130 & 228,919 & 232,694 & $1,456,337$ & $1,473,613$ \\
\hline
\end{tabular}

such as shale sintered hollow brick, shale sintered porous brick, sintering gangue porous brick and sintering heat preservation brick. The heat resistance of the different non-clay material wall is shown in Table 19. And the energy consumption results are present in Table 20. What we can know from the table is that the total energy consumption is smaller if the heat resistance is bigger.

The heat transfer through the heat bridge in the building such as column, girder can be reduced by means of painting insulation material on the heat bridge. In view of the fireproofing requirement of building, the organic material such as EPS, polyurathamc and rubber polyphenyl granule is prohibited in the insulation exterior wall. Therefore, some inorganic materials such as inorganic insulation mortar, sand autoclaved aerated concrete plate, nanometer aerated concrete plate and foaming ceramic plate are used on the heat bridge of building. The compositions of different main insulation exterior wall with different insulation material on the heat bridge were:

(1) The main wall was sand autoclaved aerated concrete block, the material on the heat bridge was inorganic insulation mortar;

(2) The main wall was sand autoclaved aerated concrete block, the material on the heat bridge was nanometer aerated concrete plate;

(3) The main wall was sand autoclaved aerated concrete block, the material on the heat bridge was sand autoclaved aerated concrete plate;

(4) The main wall was sand autoclaved aerated concrete block, the material on the heat bridge was foaming ceramic plate;

(5) The main wall was shale sintered hollow brick, the material on the heat bridge was inorganic insulation mortar.

Three kinds of typical building forms in Hangzhou were employed to carry out the dynamic simulation of the compositions of different main insulation wall with different insulation material on the heat bridge. After some necessary simplification, which had little influence on thermal environment, the plans and the 
Table 19. The heat resistance of the different non-clay material wall.

\begin{tabular}{ccc}
\hline Wall numbers & The non-clay material & Heat resistance $\left[\left(\mathrm{m}^{2} \cdot \mathrm{K}\right) / \mathrm{W}\right]$ \\
\hline (1) & sand autoclaved aerated concrete block & 1.340 \\
(2) & shale sintered hollow brick & 0.877 \\
(3) & shale sintered porous brick & 0.556 \\
(4) & sintering gangue porous brick & 0.569 \\
(5) & sintering heat preservation brick & 0.698 \\
\hline
\end{tabular}

Table 20. The energy consumption results of the different non-clay material wall (the units is $\mathrm{kW}^{\star} \mathrm{h} / \mathrm{m}^{2}$ ).

\begin{tabular}{ccccc}
\hline Wall numbers & $\begin{array}{c}\text { Energy } \\
\text { type }\end{array}$ & $\begin{array}{c}\text { Point block } \\
\text { apartment }\end{array}$ & $\begin{array}{c}\text { Stick block } \\
\text { apartment }\end{array}$ & $\begin{array}{c}\text { Office } \\
\text { building }\end{array}$ \\
\hline \multirow{2}{*}{$(1)$} & Cooling energy & 33.80 & 31.68 & 69.48 \\
& Heating energy & 21.82 & 21.74 & 34.56 \\
& Total energy & 55.62 & 53.42 & 104.04 \\
(2) & Cooling energy & 33.40 & 31.32 & 68.33 \\
& Heating energy & 31.73 & 20.16 & 39.88 \\
& Total energy & 65.13 & 51.47 & 108.21 \\
& Cooling energy & 33.70 & 31.52 & 68.57 \\
& Heating energy & 32.44 & 20.17 & 42.04 \\
& Total energy & 66.14 & 51.68 & 110.61 \\
& Cooling energy & 33.69 & 31.51 & 68.56 \\
& Heating energy & 32.42 & 20.18 & 41.93 \\
& Total energy & 66.11 & 51.69 & 110.49 \\
& Cooling energy & 33.67 & 31.49 & 68.57 \\
& Heating energy & 32.39 & 20.19 & 41.57 \\
& Total energy & 66.06 & 51.69 & 110.14 \\
\hline & & &
\end{tabular}

PKPM models of the three kinds of typical building forms are present in Figure 16. The building profiles are present in Table 21. The envelop compositions except exterior wall of the buildings are shown in Table 17.

The energy consumption results of the three kinds of typical buildings in Hangzhou are present in Table 22. From the results and the economic benefit we can find that the composition (1), (3) and (5) are more suitable for the building exterior wall in the hot summer and cold winter zone of China.

\section{The Engineering Project Study}

In order to verify the energy efficiency effect of the three compositions of exterior wall mentioned above, the tests of real building were carried out in the Group A of Xixi New World of Hangzhou. The Group A of Xixi New World is consisted of eight buildings, in which A1 - A5 are office buildings with 5 floors 

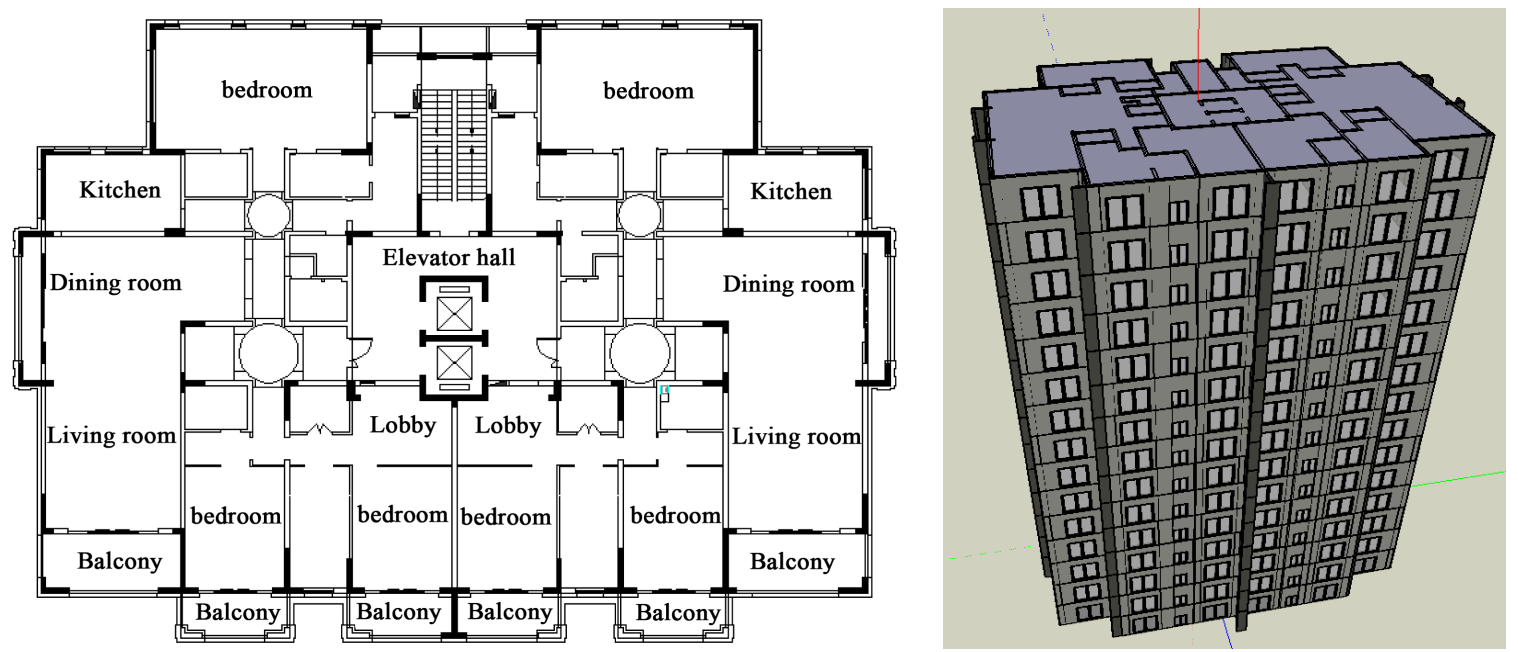

(1)
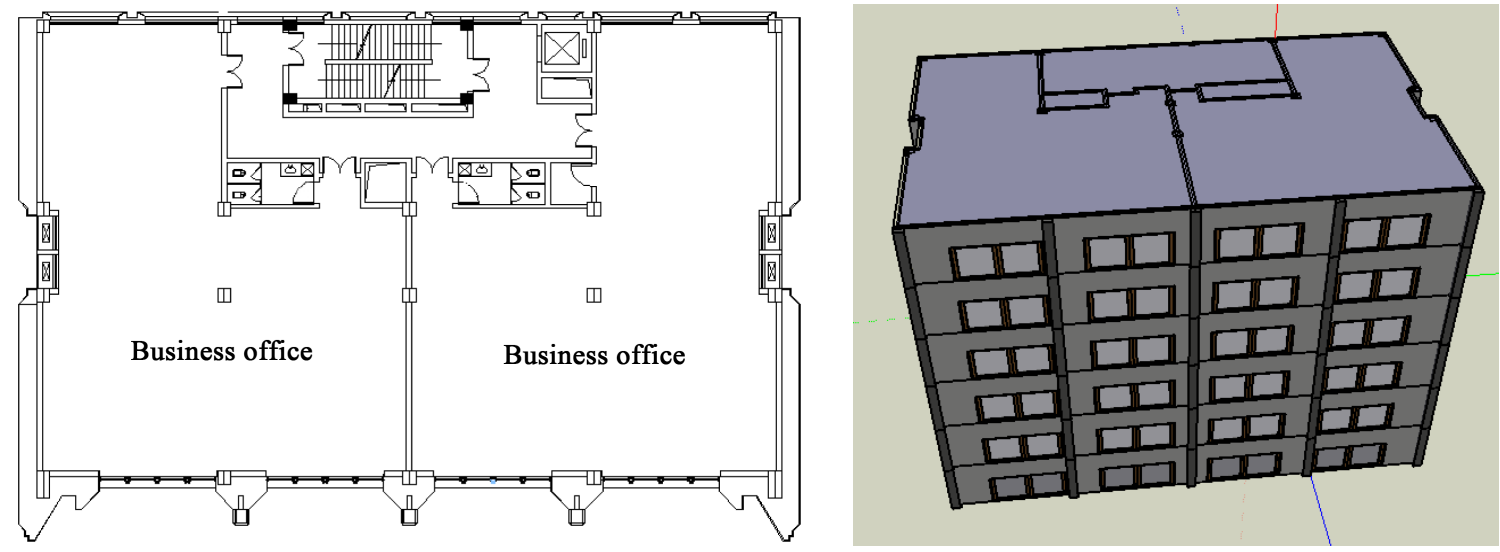

(2)
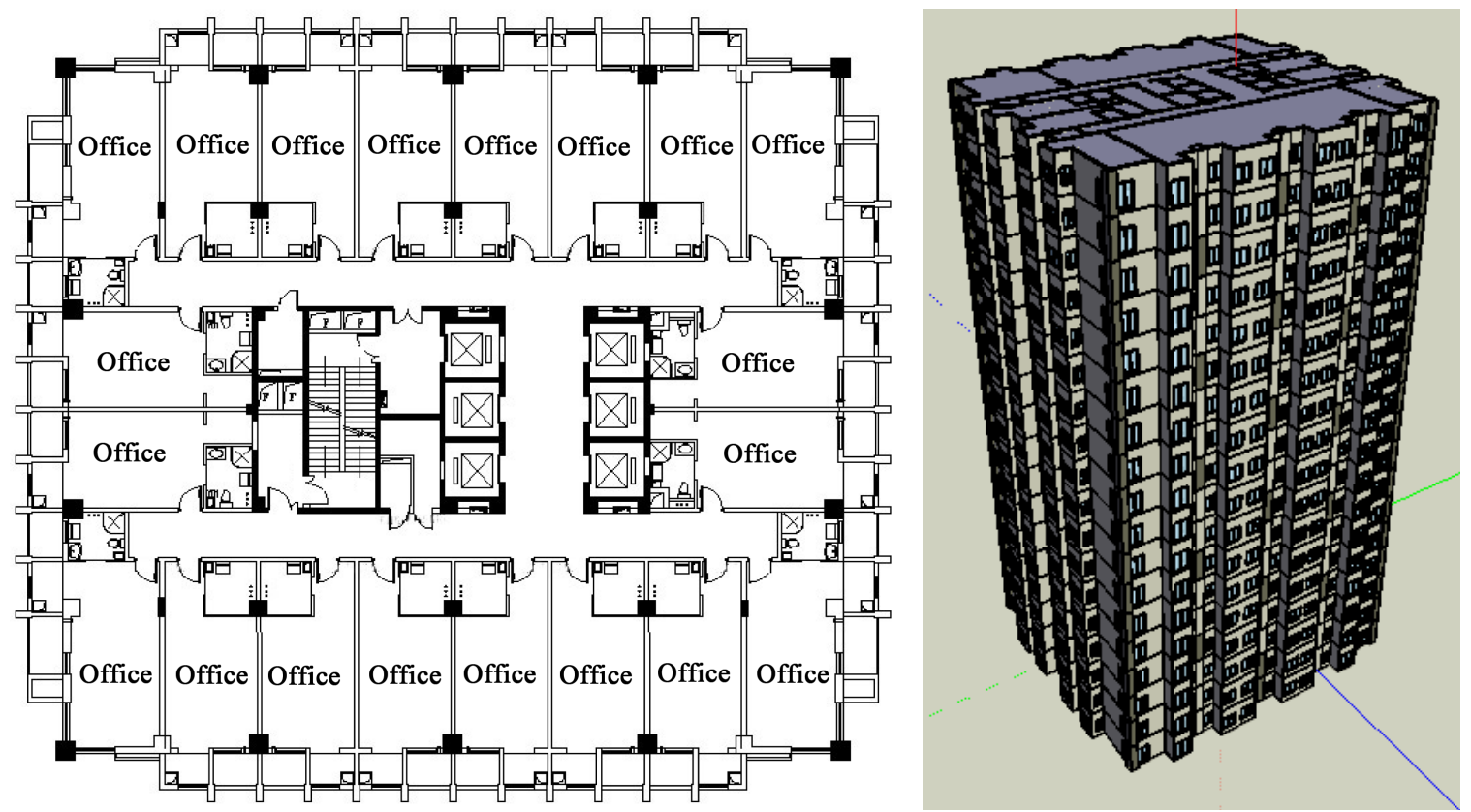

(3)

Figure 16. The plans and the PKPM models of the three kinds of typical building forms. 
Table 21. The building profiles of the three kinds of typical buildings in Hangzhou.

\begin{tabular}{|c|c|c|c|c|}
\hline \multicolumn{2}{|l|}{ City } & \multicolumn{3}{|c|}{ Hangzhou, 30 degrees north latitude and 120 degrees east longitude } \\
\hline \multicolumn{2}{|c|}{ Climate zone } & \multicolumn{3}{|c|}{ Hot summer and cold winter } \\
\hline \multicolumn{2}{|c|}{ Building type } & Apartment & Commercial building & Office building \\
\hline \multicolumn{2}{|c|}{ Orientation } & South & South & South \\
\hline \multicolumn{2}{|c|}{ Structure type } & Frame & Frame & Frame \\
\hline \multicolumn{2}{|l|}{ Floors } & 15 & 6 & 18 \\
\hline \multicolumn{2}{|c|}{ Floor height $(\mathrm{mm})$} & 3000 & 3600 & 3600 \\
\hline \multicolumn{2}{|c|}{ Shape coefficient } & 0.21 & 0.23 & 0.16 \\
\hline \multirow{4}{*}{$\begin{array}{l}\text { The area rate of } \\
\text { window to wall }\end{array}$} & East & 0.30 & 0.21 & 0.05 \\
\hline & South & 0.35 & 0.34 & 0.36 \\
\hline & West & 0.30 & 0.05 & 0.05 \\
\hline & North & 0.30 & 0.34 & 0.36 \\
\hline \multicolumn{2}{|c|}{$\begin{array}{l}\text { The area of } \\
\text { air-conditioning }\left(\mathrm{m}^{2}\right)\end{array}$} & 7589.68 & 3349.40 & 12443.90 \\
\hline \multicolumn{2}{|c|}{$\begin{array}{l}\text { The area of } \\
\text { non-air-conditioning }\left(\mathrm{m}^{2}\right)\end{array}$} & 2354.22 & 782.46 & 5347.44 \\
\hline
\end{tabular}

Table 22. The energy consumption results of the three kinds of typical buildings in Hangzhou (the units is $\mathrm{kW}^{\star} \mathrm{h} / \mathrm{m}^{2}$ ).

\begin{tabular}{ccccc}
\hline $\begin{array}{c}\text { Building } \\
\text { type }\end{array}$ & $\begin{array}{c}\text { Exterior wall } \\
\text { compositions }\end{array}$ & $\begin{array}{c}\text { Cooling } \\
\text { energy }\end{array}$ & $\begin{array}{c}\text { Heating } \\
\text { energy }\end{array}$ & $\begin{array}{c}\text { Total } \\
\text { energy }\end{array}$ \\
\hline & $(1)$ & 33.94 & 21.97 & 55.91 \\
Apartment & $(2)$ & 33.93 & 21.96 & 55.88 \\
& $(3)$ & 33.92 & 21.99 & 55.91 \\
& $(4)$ & 33.94 & 21.98 & 55.92 \\
& $(5)$ & 33.91 & 22.23 & 56.14 \\
\hline \multirow{2}{*}{$\begin{array}{c}\text { Commercial } \\
\text { building }\end{array}$} & $(1)$ & 112.93 & 23.94 & 136.42 \\
& $(2)$ & 112.95 & 23.52 & 136.47 \\
& $(3)$ & 112.98 & 23.57 & 136.55 \\
& $(4)$ & 113.12 & 23.61 & 136.73 \\
& $(5)$ & 113.30 & 23.49 & 136.79 \\
\hline $\begin{array}{c}\text { Office } \\
\text { building }\end{array}$ & $(1)$ & 73.52 & 31.49 & 105.01 \\
& $(2)$ & 73.51 & 31.59 & 105.10 \\
& $(3)$ & 73.49 & 32.02 & 105.51 \\
& $(4)$ & 31.51 & 32.48 & 106.28 \\
\hline & $(5)$ & &
\end{tabular}


and the total area is $9091 \mathrm{~m}^{2}$, A6 is a supermarket building with 4 floors and the total area is $10,744.5 \mathrm{~m}^{2}, \mathrm{~A} 7$ is a commercial building with 5 floors and the total area is $1855.7 \mathrm{~m}^{2}, \mathrm{~A} 8$ is a hotel building with 8 floors and the total area is 9169.46 $\mathrm{m}^{2}$. The 5 office buildings were test and the exterior wall of the building A1, A2 and A5 are composition (1), building A3 is composition (3), building A4 is composition (5).

The heat transfer coefficients of the exterior wall were measured by the heat flux meter, that is JW-II type temperature and heat flux auto detector. The others instruments were type MW-XQS-1821, an instrument used for testing the airtight of window and door, anemograph electric heater, voltage regulator, computer, hygrothermograph, etc. The parameters of the instruments were already illustrated in the part 2 .

The thermal resistance of the exterior wall can be calculated using the Equation (1). The heat transfer coefficient of the exterior wall is the reciprocal of the total heat resistance. Several points are test for an exterior wall in order to make the results more accurate. The average main heat resistance of the exterior wall can be calculated using the Equation (2) and the average heat transfer coefficient of the exterior wall can be calculated using the Equation (3). The relative error of the heat transfer coefficient of the exterior wall can be calculated using the Equation (4). The heat transfer coefficient of an exterior wall should be calculated using the Equation (5).

$$
R_{t}=R+R_{i}+R_{e}
$$

where, $R_{t}$ is the total heat resistance of the exterior wall; $R=\frac{\Delta T}{q}$ is the main heat resistance of the exterior wall, in which $\Delta T$ is the temperature difference measured by the heat flux meter and $q$ is the measured heat flux;

$R_{i}=0.11\left(\mathrm{~m}^{2} \cdot \mathrm{K}\right) / \mathrm{W}$ is the surface heat resistance of interior face of the exterior wall; $R_{e}=0.04\left(\mathrm{~m}^{2} \cdot \mathrm{K}\right) / \mathrm{W}$ is the surface heat resistance of exterior face of the exterior wall.

$$
R=\frac{\sum \Delta T}{\sum q}
$$

where, $\sum \Delta T$ is the temperature sum of the measuring points, $\sum q$ is the heat flux sum of the measuring points.

$$
K_{c}^{a}=\frac{\sum q}{\sum \Delta T+0.15 \sum q}
$$

where, $K_{c}^{a}$ is the average heat transfer coefficient of the measuring points of the exterior wall.

$$
\frac{\delta K}{K_{c}^{a}}=\frac{\sum \delta q \sum \Delta T+\sum \delta(\Delta T) \sum q}{\left(\sum \Delta T+0.15 \sum q\right) \sum q}
$$

where, $\delta K$ is the relative error of the heat transfer coefficient, $\delta q$ is the relative error of the heat flux, $\delta(\Delta T)$ is the relative error of the temperature 
difference.

$$
K_{c}=K_{c}^{a} \pm \delta K
$$

where, $K_{c}$ is final heat transfer coefficient of an exterior wall.

All the measures were carried out after the exterior wall had been constructed completely at least three months, which is the influence of the water in the wall could be ignored. The main exterior wall and the heat bridge were all test. The selection of the measuring points should be representative and unacted on the indirect sunlight outdoor. Besides, the measuring point of indoor air temperature was in the center of the room and $1.5 \mathrm{~m}$ away from the floor. The room should be airtight when the test was underway. The field testing photos are shown in Figure 17.
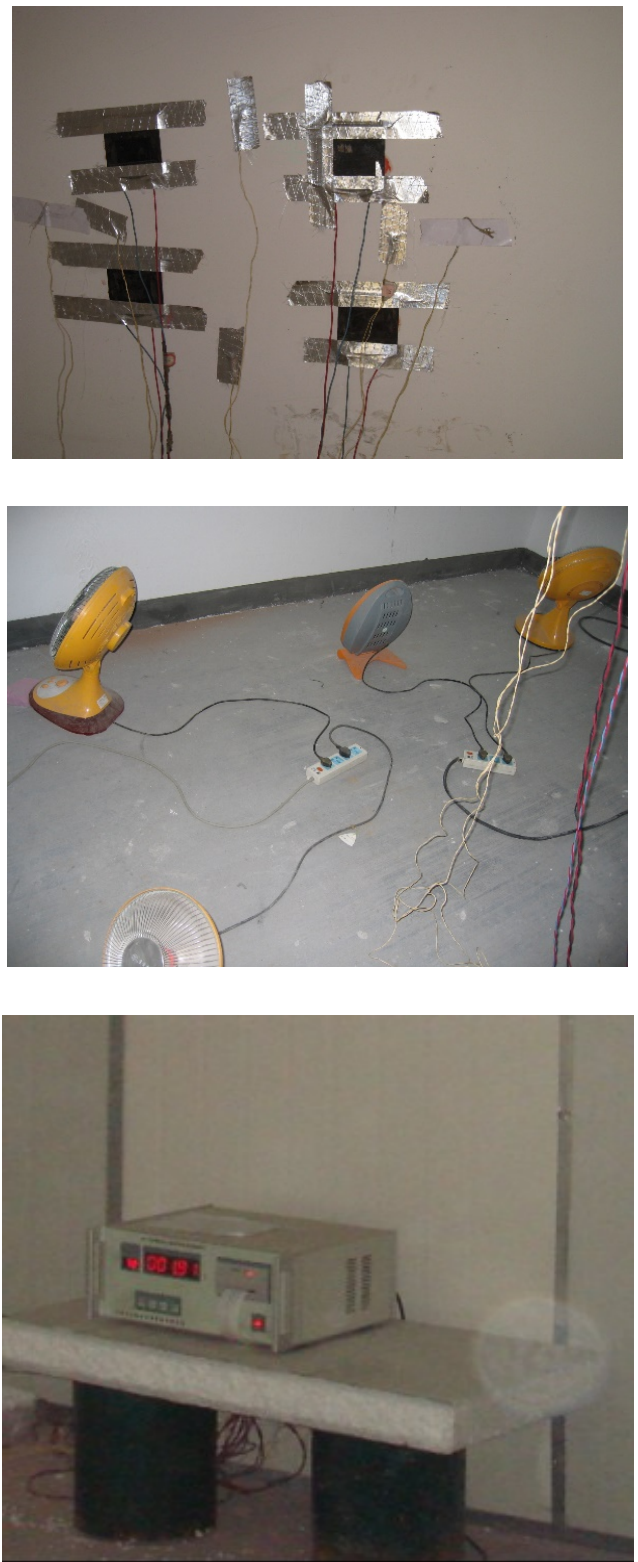

Figure 17. The field testing photos. 
Firstly, the measuring points in the building $\mathrm{A} 2, \mathrm{~A} 3$ and $\mathrm{A} 4$ are present in Figure 18. The rooms were distribution room and bathroom. The testing results of the measuring points of the building A2 are shown in Table 23. The difference of the heat transfer coefficient between the testing and theory results is $2.7 \%$ and $7.0 \%$, respectively.

Secondly, the testing results of the measuring points in the building A3 are shown in Table 24. The difference of the heat transfer coefficient between the testing and theory results is $1.4 \%$ and $2.8 \%$, respectively.

Thirdly, the testing results of the measuring points in the building A4 are shown in Table 25. The difference of the heat transfer coefficient between the testing and theory results is $5.8 \%$ and $5.3 \%$, respectively.

As we can see from the results above, the field testing results are all close to the theoretical results and the results of the indoor experiments in part 2. The heat transfer coefficient of the exterior wall of the building $\mathrm{A} 3$, in which the composition (3) was employed, is the smallest among the three recommended composition of the exterior wall.

Table 23. The testing results of the measuring points in the building A2.

\begin{tabular}{lcc}
\hline \multicolumn{1}{c}{ Parameters } & Distribution room & Bathroom \\
\hline $\begin{array}{l}\text { The average temperature of the interior surface of the testing } \\
\text { wall }\left[{ }^{\circ} \mathrm{C}\right]\end{array}$ & 42.5 & 45.0 \\
$\begin{array}{l}\text { The average temperature of the exterior surface of the testing } \\
\text { wall }\left[{ }^{\circ} \mathrm{C}\right]\end{array}$ & 29.4 & 27.7 \\
$\begin{array}{l}\text { The average temperature difference between the interior and } \\
\text { exterior surface of the testing wall }\left[{ }^{\circ} \mathrm{C}\right]\end{array}$ & 13.1 & 17.3 \\
$\begin{array}{l}\text { The average heat flux of the testing wall }\left[\mathrm{W} / \mathrm{m}^{2}\right] \\
\text { The heat resistance } \mathrm{R} \text { of the testing wall }\left[\left(\mathrm{m}^{2} \cdot \mathrm{k}\right) / \mathrm{W}\right]\end{array}$ & 25.36 & 14.89 \\
$\begin{array}{l}\text { The total heat resistance } R_{t} \text { of the testing } \mathrm{wall}\left[\left(\mathrm{m}^{2} \cdot \mathrm{k}\right) / \mathrm{W}\right] \\
\text { The heat transfer coefficient } \text { of the testing } \mathrm{wall}\left[\mathrm{W} /\left(\mathrm{m}^{2} \cdot \mathrm{k}\right)\right]\end{array}$ & 0.517 & 1.162 \\
The heat transfer coefficient in theory $\left[\mathrm{W} /\left(\mathrm{m}^{2} \cdot \mathrm{k}\right)\right]$ & 0.667 & 1.312 \\
\hline
\end{tabular}

Table 24. The testing results of the measuring points in the building A3.

\begin{tabular}{lcc}
\hline \multicolumn{1}{c}{ Parameters } & Distribution room & Bathroom \\
\hline $\begin{array}{l}\text { The average temperature of the interior surface of the testing } \\
\text { wall }\left[{ }^{\circ} \mathrm{C}\right]\end{array}$ & 41.5 & 43.8 \\
$\begin{array}{l}\text { The average temperature of the exterior surface of the testing } \\
\text { wall }\left[{ }^{\circ} \mathrm{C}\right]\end{array}$ & 29.5 & 26.7 \\
$\begin{array}{l}\text { The average temperature difference between the interior and } \\
\text { exterior surface of the testing wall }\left[{ }^{\circ} \mathrm{C}\right]\end{array}$ & 12.0 & 17.1 \\
$\begin{array}{l}\text { The average heat flux of the testing wall }\left[\mathrm{W} / \mathrm{m}^{2}\right] \\
\text { The heat resistance } \mathrm{R} \text { of the testing wall }\left[\left(\mathrm{m}^{2} \cdot \mathrm{k}\right) / \mathrm{W}\right]\end{array}$ & 21.81 & 13.96 \\
The total heat resistance $R_{t}$ of the testing $\mathrm{wall}\left[\left(\mathrm{m}^{2} \cdot \mathrm{k}\right) / \mathrm{W}\right]$ & 0.550 & 1.225 \\
The heat transfer coefficient of the testing $\mathrm{wall}\left[\mathrm{W} /\left(\mathrm{m}^{2} \cdot \mathrm{k}\right)\right]$ & 0.700 & 1.375 \\
The heat transfer coefficient in theory $\left[\mathrm{W} /\left(\mathrm{m}^{2} \cdot \mathrm{k}\right)\right]$ & 1.43 & 0.73 \\
\end{tabular}



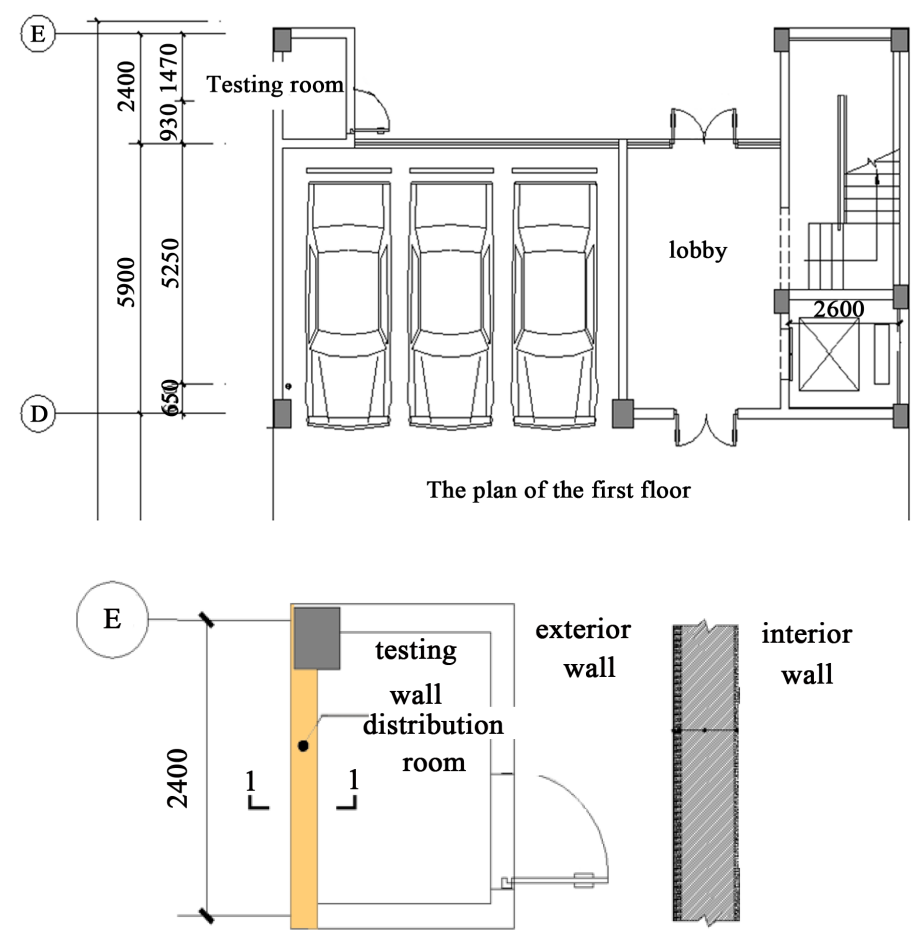

The plan of the testing room

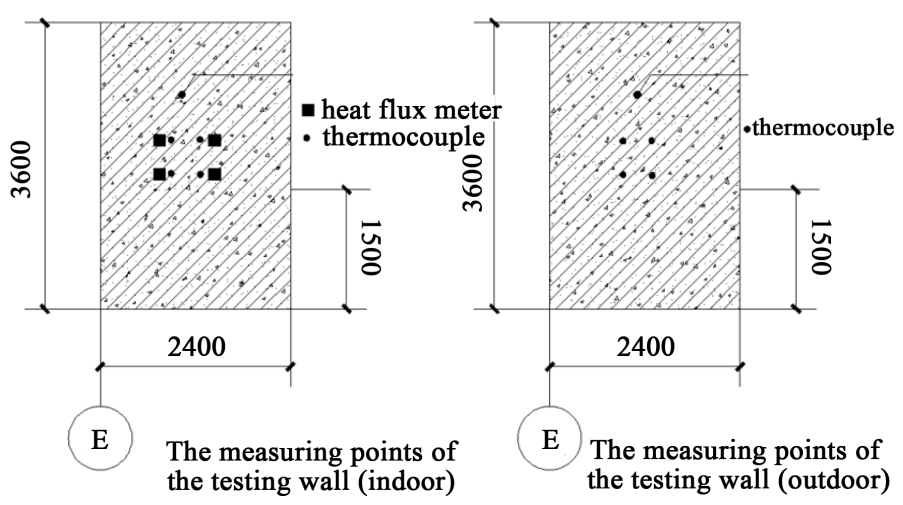

(1) distribution room

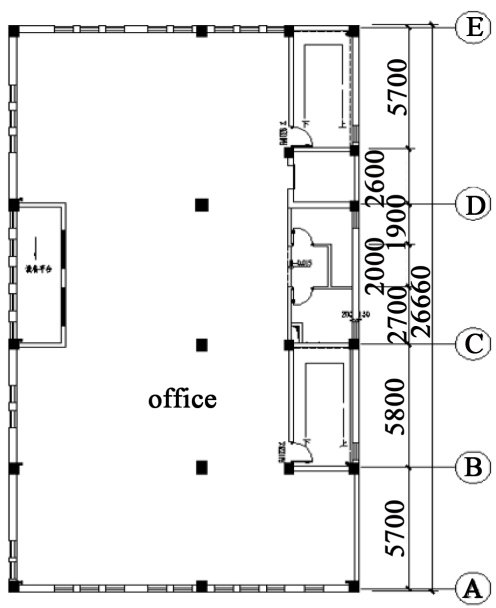

The plan of the second floor 


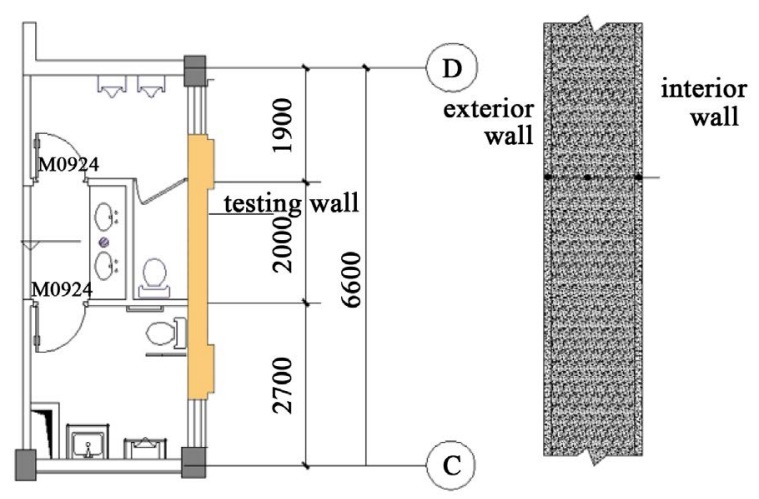
The plan of the testing
room

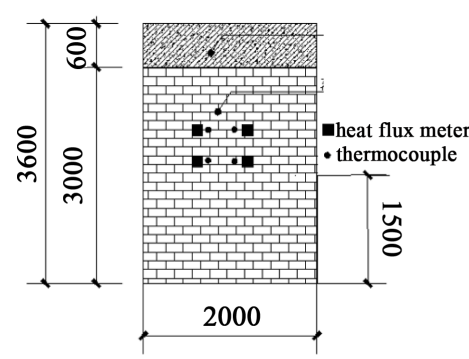

The measuring points of the testing wall (indoor)
$1-1$

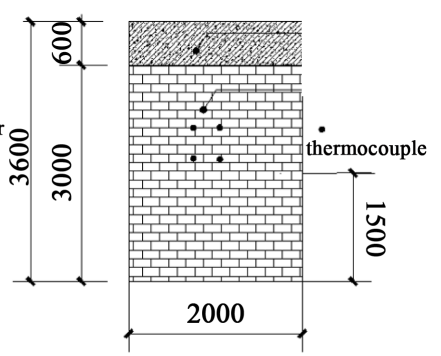

The measuring points of the testing wall (outdoor)

(2) bathroom

Figure 18. The measuring points in the building A2, A3 and A4.

Table 25. The testing results of the measuring points in the building A4.

\begin{tabular}{lcc}
\hline \multicolumn{1}{c}{ Parameters } & Distribution room & Bathroom \\
\hline $\begin{array}{l}\text { The average temperature of the interior surface of the testing } \\
\text { wall }\left[{ }^{\circ} \mathrm{C}\right]\end{array}$ & 43.0 & 43.8 \\
$\begin{array}{l}\text { The average temperature of the exterior surface of the testing } \\
\text { wall }\left[{ }^{\circ} \mathrm{C}\right]\end{array}$ & 31.3 & 30.2 \\
$\begin{array}{l}\text { The average temperature difference between the interior and } \\
\text { exterior surface of the testing wall }\left[{ }^{\circ} \mathrm{C}\right]\end{array}$ & 11.7 & 13.6 \\
$\begin{array}{l}\text { The average heat flux of the testing wall }\left[\mathrm{W} / \mathrm{m}^{2}\right] \\
\text { The heat resistance } R \text { of the testing wall }\left[\left(\mathrm{m}^{2} \cdot \mathrm{k}\right) / \mathrm{W}\right]\end{array}$ & 15.37 & 15.73 \\
The total heat resistance $R_{t}$ of the testing $\mathrm{wall}\left[\left(\mathrm{m}^{2} \cdot \mathrm{k}\right) / \mathrm{W}\right]$ & 0.761 & 0.865 \\
The heat transfer coefficient of the testing $\mathrm{wall}\left[\mathrm{W} /\left(\mathrm{m}^{2} \cdot \mathrm{k}\right)\right]$ & 0.911 & 1.015 \\
The heat transfer coefficient in theory $\left[\mathrm{W} /\left(\mathrm{m}^{2} \cdot \mathrm{k}\right)\right]$ & 1.10 & 0.99 \\
\hline
\end{tabular}

\section{Conclusions}

The hot summer and cold winter zone of China is a main climate zone of China. The energy efficiency design of the exterior wall in the buildings of the zone should consider the heat prevention in summer and the heat insulation in winter. Because of the serial problems found in the practical application of common insulation forms such as interior insulation and exterior insulation, the self-insulation of the exterior wall is a feasible design to satisfy the energy efficiency 
of buildings in the zone. However, the systematic research is urgently needed for the self-insulation of the exterior wall in the hot summer and cold winter zone of China.

Firstly, the thermal performance of the common materials using in the self-insulation of the exterior wall were test by means of indoor experiments. The common non-clay wall materials are shale sintered hollow brick, sand autoclaved aerated concrete block, shale sintered porous brick, sintering gangue porous brick, sintering heat preservation brick and composite concrete porous brick. The conclusions are as follows.

The density and the thermal conductivity of the six non-clay wall material are all smaller than the density and the thermal conductivity of the clay porous brick, which is $1400 \mathrm{~kg} / \mathrm{m}^{3}$ and $0.58 \mathrm{~W} /(\mathrm{m} \cdot \mathrm{K})$, respectively. Besides, the porosity of the six non-clay wall material are all bigger than the porosity of the clay porous brick, which is about $30 \%$. Therefore, the non-clay brick can be used as new wall material of energy efficient.

Commonly, the thermal performance of the non-clay brick can be improved obviously through the rational arrangement of the holes such as modularizing the holes, filling the holes with insulation material such as EPS and adding insulation material in the raw material. Think of filling the holes with EPS is not appropriate for mass production, rational arrangement of the holes and adding insulation material become the feasible means to improve the thermal performance further of the non-clay bricks.

Comparing comprehensively the results mentioned above, two materials, shale sintered hollow brick after increasing the holes and rationalizing the hole arrangement and sand autoclaved aerated concrete block are recommended as the more proper material used in the insulation wall of building in the hot summer and cold winter area of China.

Secondly, the energy efficiency effect of the common materials was verified using dynamic calculation soft PKPM and several constitutions of exterior wall with different main bricks and insulation materials on the heat bridge were simulated, too. The conclusions are: the thermal performance of the non-clay materials are all satisfied with the energy efficiency because of the total energy consumption of the buildings using non-clay bricks are all smaller than the base cases; the total energy consumption is smaller if the heat resistance is bigger; from the simulated results and the economic benefit, three kinds of compositions of the exterior wall with different main wall materials and insulation materials on the heat bridge are recommended for the building exterior wall in the hot summer and cold winter zone of China.

Finally, the tests of the thermal performance of the exterior wall based on the real constructions were carried out to testify the practical effect of the recommended constitutions of exterior wall with different main bricks and insulation materials on the heat bridge. All the testing results are close to the theoretical results and the results of the indoor experiments in part 2. The heat transfer coefficient of the exterior wall with composition (3), in which the main wall was 
sand autoclaved aerated concrete block and the material on the heat bridge was sand autoclaved aerated concrete plate, is the smallest among the three recommended compositions.

\section{Acknowledgements}

The researches of the paper were entrusted by the Leading Group Office of Innovation Wall of Hangzhou, leaded by The Architectural Design and Research Institute of Zhejiang University Co, Ltd. The associate companies and institutes were Institute of Architectural Technology of Zhejiang University, Construction Group of Canhigh Co, Ltd, Zhejiang Kaiyuan Building Material Company and The Fourth Constructional Engineering Company of Hangzhou, etc.

\section{References}

[1] Sonderegger R.C. (1977) Harmonic Analysis of Building Thermal Response Applied to the Optimal Location of Insulation within the Walls. Energy and Buildings, 1, 131-140. https://doi.org/10.1016/0378-7788(77)90025-1

[2] Bojic, M., Yik, F. and Sat, P. (2001) The Influence of Thermal Insulation Position in Building Envelope on the Space Cooling of High Rise Residential Buildings in Hong Kong. Energy and Buildings, 33, 569-581. https://doi.org/10.1016/S0378-7788(00)00125-0

[3] Kossecka, E. and Kosny, J. (2002) The Influence of Insulation Configuration on Heating and Cooling Loads in a Continuously Used Building. Energy and Buildings, 34, 321-331. https://doi.org/10.1016/S0378-7788(01)00121-9

[4] Zhu, G.J. and Zhang, X.L. (2005) The Influence of Exterior Wall Thermal Insulation Technology on Air Conditioning Load. Energy Conservation Technology, 23, 30-33.

[5] Ning, Y.F., Liu, Z.H. and Chen, G. (2006) The Influence of Exterior Wall Thermal Insulation on Air Conditioning Load of Residential Building in Hot Summer and Cold Winter Zone. Journal of Huaihua University, 5, 113-115.

[6] Tsilingiris, P.T. (2006) Wall Heat Loss from Intermittently Conditioned SpacesThe Dynamic Influence of Structural and Operational Parameters. Energy and Buildings, 38, 1022-1031. https://doi.org/10.1016/j.enbuild.2005.11.012

[7] Ozel, M. and Pihtili, K. (2007) Optimum Location and Distribution of Insulation Layers on Building Walls with Various Orientations. Building and Environment, 42, 3051-3059. https://doi.org/10.1016/j.buildenv.2006.07.025

[8] Yu, J.H., Yang, C.Z. and Tian, L.W. (2008) Low-Energy Envelope Design of Residential Building in Hot Summer and Cold Winter Zone in China. Energy and Buildings, 40, 1536-1546. https://doi.org/10.1016/j.enbuild.2008.02.020

[9] Ibrahim, M., Ghaddar, N. and Ghali, K. (2012) Optimal Location and Thickness of Insulation Layers for Minimizing Building Energy Consumption. Journal of Building Performance Simulation, 5, 384-398. https://doi.org/10.1080/19401493.2012.657686

[10] Kolaitis, D.I., Malliotakis, E., Kontogeorgos, D.A., Mandilaras, I., Katsourinis, D.I. and Founti, M.A. (2013) Comparative Assessment of Internal and External Thermal Insulation Systems for Energy Efficient Retrofitting of Residential Buildings. Energy and Buildings, 64, 123-131. https://doi.org/10.1016/j.enbuild.2013.04.004

[11] Fisher, D.E. and Pedersen, C.O. (1997) Convective Heat Transfer in Building Energy and Thermal Load Calculations. ASHRAE Transactions, 103, Pt. 2. 
[12] Ma, Z.L. and Yao, Y. (2010) Air Conditioning Design of Civil Buildings. Chemical Industry Press, Beijing.

[13] Su, Y.F., Zhou, X.C., and Ma, X.J. (2011) The Contrast of the Ground Temperature and the Grass Surface Temperature. Serves of Agricultural Technology, 28, 127, 133.

[14] Zhao, R.Y. and Fan, C.Y. (1994) Air Conditioning. The Building Industry Press of China, Beijing.

Submit or recommend next manuscript to SCIRP and we will provide best service for you:

Accepting pre-submission inquiries through Email, Facebook, LinkedIn, Twitter, etc. A wide selection of journals (inclusive of 9 subjects, more than 200 journals)

Providing 24-hour high-quality service

User-friendly online submission system

Fair and swift peer-review system

Efficient typesetting and proofreading procedure

Display of the result of downloads and visits, as well as the number of cited articles

Maximum dissemination of your research work

Submit your manuscript at: http://papersubmission.scirp.org/

Or contact epe@scirp.org 